\title{
Desalination: From Ancient to Present and Future
}

\author{
Andreas N. Angelakis 1,2 (D), Mohammad Valipour ${ }^{3,4, *}$, Kwang-Ho Choo ${ }^{5}$ D, Abdelkader T. Ahmed ${ }^{6,7}(\mathbb{D}$, \\ Alper Baba ${ }^{8}$, Rohitashw Kumar ${ }^{9} \mathbb{D}$, Gurpal S. Toor ${ }^{10} \mathbb{D}$ and Zhiwei Wang ${ }^{11}$
}

check for updates

Citation: Angelakis, A.N.; Valipour, M.; Choo, K.-H.; Ahmed, A.T.; Baba, A.; Kumar, R.; Toor, G.S.; Wang, Z. Desalination: From Ancient to Present and Future. Water 2021, 13, 2222. https://doi.org/10.3390/ w13162222

Academic Editor: Pei Xu

Received: 2 July 2021

Accepted: 12 August 2021

Published: 16 August 2021

Publisher's Note: MDPI stays neutral with regard to jurisdictional claims in published maps and institutional affiliations.

Copyright: (c) 2021 by the authors. Licensee MDPI, Basel, Switzerland. This article is an open access article distributed under the terms and conditions of the Creative Commons Attribution (CC BY) license (https:// creativecommons.org/licenses/by/ $4.0 /)$.
1 HAO-Demeter, Agricultural Research Institution of Crete, 71300 Iraklion, Greece; angelak@edeya.gr 2 Union of Hellenic Water Supply and Sewerage Operators, 41222 Larissa, Greece

3 Water Resources Research Center, Department of Civil and Environmental Engineering, University of Hawaii at Manoa, Honolulu, HI 96822, USA

4 Center of Excellence for Climate Change Research, Department of Meteorology, King Abdulaziz University, Jeddah 21589, Saudi Arabia

5 Department of Environmental Engineering, Kyungpook National University, 80 Daehak-ro, Buk-gu, Daegu 41566, Korea; chookh@knu.ac.kr

6 Civil Engineering Department, Faculty of Engineering, Aswan University, Aswan 81542, Egypt; dratahmed@yahoo.com

7 Civil Engineering Department, Faculty of Engineering, Islamic University, Madinah 42351, Saudi Arabia

8 Department of International Water Resources, Izmir Institute of Technology, 35430 Izmir, Turkey; alperbaba@iyte.edu.tr

9 College of Agricultural Engineering and Technology, SKUAST-Kashmir, Srinagar (J\&K) 190025, India; rohituhf@rediffmail.com

10 Department of Environmental Science and Technology, University of Maryland, College Park, MD 20742, USA; gstoor@umd.edu

11 State Key Laboratory of Pollution Control and Resource Reuse, Shanghai Institute of Pollution Control and Ecological Security, School of Environmental Science and Engineering, Tongji University,

Shanghai 200092, China; zwwang@tongji.edu.cn

* Correspondence: vali-pour@hotmail.com

Abstract: Water is life, and without water, there would be no civilizations and a vacant Earth. Water is considered an abundant natural resource on the earth. Water covers $3 / 4$ of the surface. However, $97 \%$ of the available water on the earth is salty oceanic water, and only a tiny fraction $(3 \%)$ is freshwater. This small portion of the available water supplies the needs of humans and animals. However, freshwater exists in underground, rivers, and lakes and is insufficient to cover all the world's water demands. Thus, water saving, water reuse, rainwater harvesting, stormwater utilization, and desalination are critical for maintaining water supplies for the future of humanity. Desalination has a long history spanning centuries from ancient times to the present. In the last two decades, desalination has been rapidly expanding to meet water needs in stressed water regions of the world. Yet, there are still some problems with its implementation in several areas of the world. This review provides a comprehensive assessment of the history of desalination for wiser and smarter water extraction and uses to sustain and support the water needs of the earth's inhabitants.

Keywords: distillation; evaporation; Persian Gulf; reverse osmosis; seawater; brackish water; sustainable development; wastewater treatment and reuse

\section{Introduction}

The history of water is equivalent to the history of the world and the history of water quality is equivalent to the history of life.

-Andreas N. Angelakis

"...saltwater is being mixed with something else is an evident not only from what was said but by whether someone after building a wax-vessel, put in the sea while having tie around the orifice in such a manner as not to be poured into the seawater. This (water), thus coming in through the wax-vessel walls, is drinkable (water), such that the separated 
soil substances (from the water) with filtration, so what makes the water salty is mixing (with something else)...". (Aristotle (384-322 BC, Meteorologia, Book B')

Desalination has been an ongoing process on earth-the natural process of water evaporation from the sea and the condensation in the atmosphere to form rain. The freezing of available seawater near the Polar and Arctic Regions, where different ice crystals are shaped, originates from pure water as salt is excluded from crystal growth [1].

Since the Megalithic period ( $c a .6000 \mathrm{BC}$ ), successive hot periods in the Mediterranean region contributed to significant progress in water resources practices and management. The funeral monument of Alcalar (Portimão, Portugal) is an excellent example of that period. Many remarkable achievements in the different periods of Prehistoric times ( $c a$. 3200-1100 BC), including various hydro-technologies, navigation, and trade, were experienced [2]. During the Atlantic Bronze Age, initiated in ca. 1300 BC, an intense trade (copper, tin, and gold) took place among the west end of the Iberian Peninsula, Bretagne, and the British Islands [3]. Minoan sailors were dominant in the Mediterranean Sea and probably implemented desalination for thousands of years by boiling water to evaporate and separate freshwater from the salt. Minoan technologies, including hydraulics and navigation, were exported to the mainland in later periods of the Greek civilizations in the Mycenaean, Archaic, Classical, Hellenistic, and Roman periods [4]. In the Roman and Hellenistic eras, major developments were made in hydraulics and navigation, such as the construction and operation of large-scale ships.

There is reported information that the Greeks first expressed philosophical opinions about the nature of water. Thales of Miletus ( $c$. 624-548 BC), the founder of the Ionia School and one of the famous seven wise men of antiquity, reported about water that is fertile and molded as water. Additionally, Thales mentioned seawater consists of the immense sea surrounding the whole planet, which is the main element of the existing life on the earth [5]. Later on, Embedokles (ca. 490-430 BC), born in Sicily, introduced the theory of the major elements describing that the world consists of four main elements: earth, water, air, and fire [6]. Considering our current knowledge and experience, those main elements that affect human life quality could be converted to water, soil, energy, and atmosphere [7].

In a cold period, around $750 \mathrm{BC}$, the Phoenicians and later the Carthaginians arrived on Portuguese coasts. They were sailors and traders from the actual Lebanon and Tunisia. Probably it was during this period that irrigation was introduced, together with the waterwheel Nora and the Shaduf (hand-operated device for lifting water, invented in ancient times). The presence of Greek sailors on the Iberian coast is also documented between $c a$. 630 and $535 \mathrm{BC}$ [3].

Historically, desalination has been known through the centuries both as a concept and technology. However, only in the late Archaic times, in Miletus Ionian philosophers identified which all freshwater on the globe can be reused. In China, the Classic of Mountains and Seas in the Period of Warring States (ca. 475-221 BC) showed that the bamboo mats long-term used for steaming rice could form a thin outer layer, which had functions of adsorption and ion exchange for adsorbing salt [8]. Later, the Greek philosopher Aristotle (384-322 BC) recognized that the water phase might be changed, and the exchange of energy in his relative work that has been published and pointed out that saltwater could become sweet by turning vapor, but it does not turn back to saltwater again when it condenses. He reported that a suitable wax vessel, when submerged in seawater for a long time, holds potable water and filters the salt [9].

Although large-scale desalination plants were not feasible until the end of World War II $[10,11]$, numerous examples of experimentation about desalination technologies throughout ancient times are available [6,10]. For example, in ca. 200 AD, Alexander of Aphrodisias referred desalination process applied by sailors. At that time, the ancient people boiled seawater to produce steam, which was absorbed by sponges and produced potable water [6]. 
Before the Industrial Revolution, desalination was primarily used for ocean-bound ships, which otherwise needed to be supplied with freshwater. Thomas Jefferson came up with a better method to desalinate on ships based on heat in the USA. The desalination methods have been developed since the 1500s.

Decals with his instructions were prepared, publicized, and placed on all USA ships on the backs of clearance sailing permits [12].

After World War II, significant research for the improvement of desalination technologies was conducted in the USA. The US Department of the Interior built the Office of Saline Water by the Saline Water Conversion.

In 1974, it was merged into the Office of Research of Water Resources. The investigations also took place at several universities, followed by development at different chemical companies [13]. Thus, seawater desalination technology for potable water production has evolved rapidly and has become quite usable [14].

With the increasing population and the demand for freshwater, entrepreneurs began to seek technologies of producing potable water in remote zones and mainly on ships and boats at sea [15].

As a result, various technologies focusing on optimizing desalination practices have been reported $[16,17]$. Nowadays, many countries worldwide, especially in the Middle East, rely highly on desalination technologies.

In contrast, many more have turned in the development of desalination and diversify their water supply alternatives for sustainable technologies and climate fluctuations challenges. Worldwide seawater desalination capacity is enhancing at a rapid rate.

According to International Desalination Association (IDA) about 28 million $\mathrm{m}^{3} / \mathrm{d}$ desalinated water from oceans and regional seas is produced all over the world [18,19]. Regarding the coastal zones, the highest number of desalination plants with a capacity of about 12.1 million $\mathrm{m}^{3} / \mathrm{d}$, corresponding to $44 \%$ of the daily production on the global scale, are found in the Persian Gulf.

The major producers in the Persian Gulf are located in Saudi Arabia (50\%), UAE (23\%), and Kuwait (6\%).

Desalination using thermal processes dominates in the Persian Gulf countries (94\% of the total production), as water and power are usefully generated using big co-generation plants that apply steam from large power plant turbines as a reliable source of heat desalination.

Most of the water (81\%) is generated in the Persian Gulf via multi-stage flash distillation (MSF). Multi-effect distillation (MED) (13\% of the production) and reverse osmosis (RO) $(6 \%$ of the production) are the other processes $[18,19]$.

Further, water desalination across the world appears to be more complicated than that during ancient periods. In a chronological view, one may argue for five epochs of desalination, each singled out by its distinct characteristics: (a) Prehistoric Era (ca. 35001100 BC), (b) Historical Era (ca. 750 BC-330 AD), (c) Medieval Era (ca. 330-1400 AD), (d) Early Modern and Modern Era (ca. 1400-1850 AD), and (e) Contemporary Era (1850 AD-present).

It is necessary to consider a comprehensive overview of the history of water desalination to improve our knowledge about the causes, events, and consequences. Emerging trends in desalination are considered. Such information is necessary to prevent future desalination issues and challenges by improving proper water governance frameworks. Study the history, if you would define the future, Confucius (551 BC to 479 BC).

This paper is organized as follows: Section 1 Prolegomena is an introductory to the theme and elements of the review, followed by Sections 2-4 that explain the distinct histories of desalination from the prehistoric era to present time in a geographical and chronological view, including various types of technology used and sources of water. Section 5 represents emerging trends and possible future challenges, and Section 6 focuses on the future issues and challenges of desalination. Finally, Section 7 is the epilogue that includes conclusive remarks and highlights. 


\section{Desalination from Prehistoric to Medieval Era (ca. 3200 BC-1400 AD)}

\subsection{Bronze Age (ca. 3200-1100 BC)}

An ancient civilization in the Bronze Age was comprised of copper smelting, alloys with tin, or trading for bronze. The major Bronze Age cultures were as follows in different regions of the world:

(a) The Egyptian civilizations (ca. 4000-550 BC).

(b) In Mesopotamia, the Bronze Age from about 3200 to 1100 BC was comprised of: (i) Sumerians (ca. 4000-2000 BC), who were politically divided between competing city-states, each controlled at least by a dynasty, and were succeeding by the Akkadian Period (ca. 2350-2150 BC); (ii) The Assyria Kingdom or/and Empire (ca. 2500 BC-605 BE); (iii) Babylonian Kingdom (2000-1595 BC); (iv) Kassite culture (ca. 1595-1155 BC); and (v) Hittites Empire (ca. 1600-800 BC).

(c) In the Aegean region, the Minoans established at the Bronze Age began around $3200 \mathrm{BC}$, in a far-ranging trade network for copper used with tin for bronze production. The navigation knowledge, which was developed in that era, reached the top of skill since the end of Minoan civilization around 1200 BC. The center of Minoans was the island of Crete.

In Cyprus, the Bronze Age (ca. 2500-1050 BC) was an era of growth and foreign occupation of the island. In ca. 1100 BC, after the war with Troy, the Mycenaean Greeks stayed on the island. The Cypriot Archaic period (ca. 750-475 BC) was a problematic era for the island inhabitants, such as the Assyrians, Persians, and Egyptians, who succeeded one another as rulers of the island.

Finally, a successive civilization of Minoans and ancient Cypriots was the Mycenean (ca. 1600-1100 BC), which flourished in the southeastern areas of the Greek mainland.

(d) The early Bronze Age Unitive culture in Central Europe (ca. 1800-1600 BC) included numerous smaller groups, such as the Straubing, Adlerberg, and Hatvan cultures, considered wealthy burials. The Bronze Age followed the Unetice culture (ca. 1600-1200 BC) Tumulus culture characterized by inhumation burials in tumuli (barrows).

Starting with the early civilization of prehistoric times, a preliminary review of the potable water treatment, including the sea water by the Minoan sailors, is considered. From the beginning of the Bronze Age (ca. 3200-1100 BC), one of the salient characteristics of the Minoans was the treatment of potable water in palaces, cities, and villages by using appropriate devices. Remarkably, the Minoan "engineers" were aware of the most common water quality improvement practices for preparing suitable potable water supplies. A strange, clay-made oblong water filter known as Defner (1921) with an opening at its ends was used for treating the water supply [20]. The device was built similarly to other ceramic materials, e.g., the ceramic filters were developed later on (Figure 1). Spanakis [20] is considered a hydraulic filter that was well connected by a rope to a water supply reservoir. Its operation relied on high-speed turbulent hydraulic conditions to continuously clean the filter's porous surface and allow the flow of filtered water to a portable water container. After extensive solids accumulation during cleaning, by loosening the rope from the holes, it was possible to remove the solids from the end of the pipe [21].

The Minoan ceramic filter could be considered as a precursor of the ceramic membranes. Minoan sailors first produced drinking water from seawater. Muge and Loukovikas [22] reported that the Minoans came with their merchant fleet to dominate the seas, sailing long distances, from the west to the east of the Mediterranean Sea, searching for trade. It was possibly a measure for the Minoans' geographical isolation and the strengths of their fleet in coastal areas to have a few fortifications. However, their period of progress was called the Pax Minoica or 'Minoan peace' — a time when cities needed no walls [23].

This is also evidenced by the absence of fortification facilities in all palaces, cities, and other settlements that have been discovered. In contrast, thereafter, civilizations were founded, e.g., 'cyclopean' walls of the Mycenaeans, the Roman castellum or fortress, and other military constructions. Hirschfeld [24] reported that Crete was appropriately placed in strong relation to trading routes at sea. 


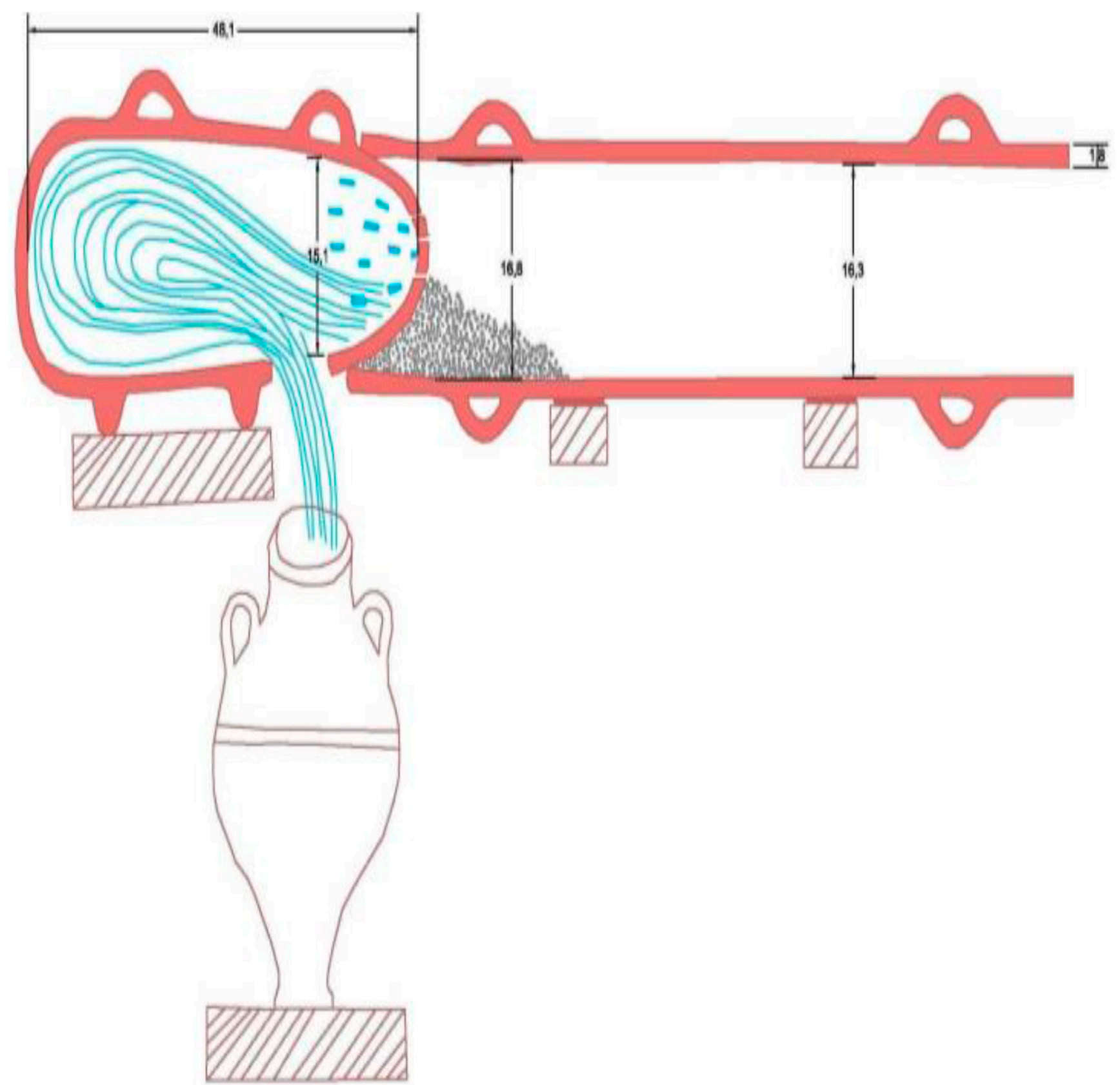

Figure 1. Water ceramic filter (adapted from [21]).

Thucydides, in $431 \mathrm{BC}$, in his first book, History of the Peloponnesian War, reported that: "And the first person known to us by tradition as having established a navy is Minos. He made himself master of what is now called the Hellenic Sea and ruled over the Cyclades, into most of which he sent the first colonies... and thus did his best to put down piracy in those waters, a necessary step to secure the revenues for his own use".

Minoans developed and used various types of ships probably since ca. $1500 \mathrm{BC}$, as demonstrated by the paintings discovered by the Spyridon Marinatos, a Greek archaeologist, in "Akrotiri" Thera (Figure 2). These are parts of a Fresco. Additionally, it is fascinating that there is not a visible waterline, and all the ships look in a floating status over the sea [25]. Similarly, the frieze of the fleet in Thira with Minoan ships was reported by [22]. 


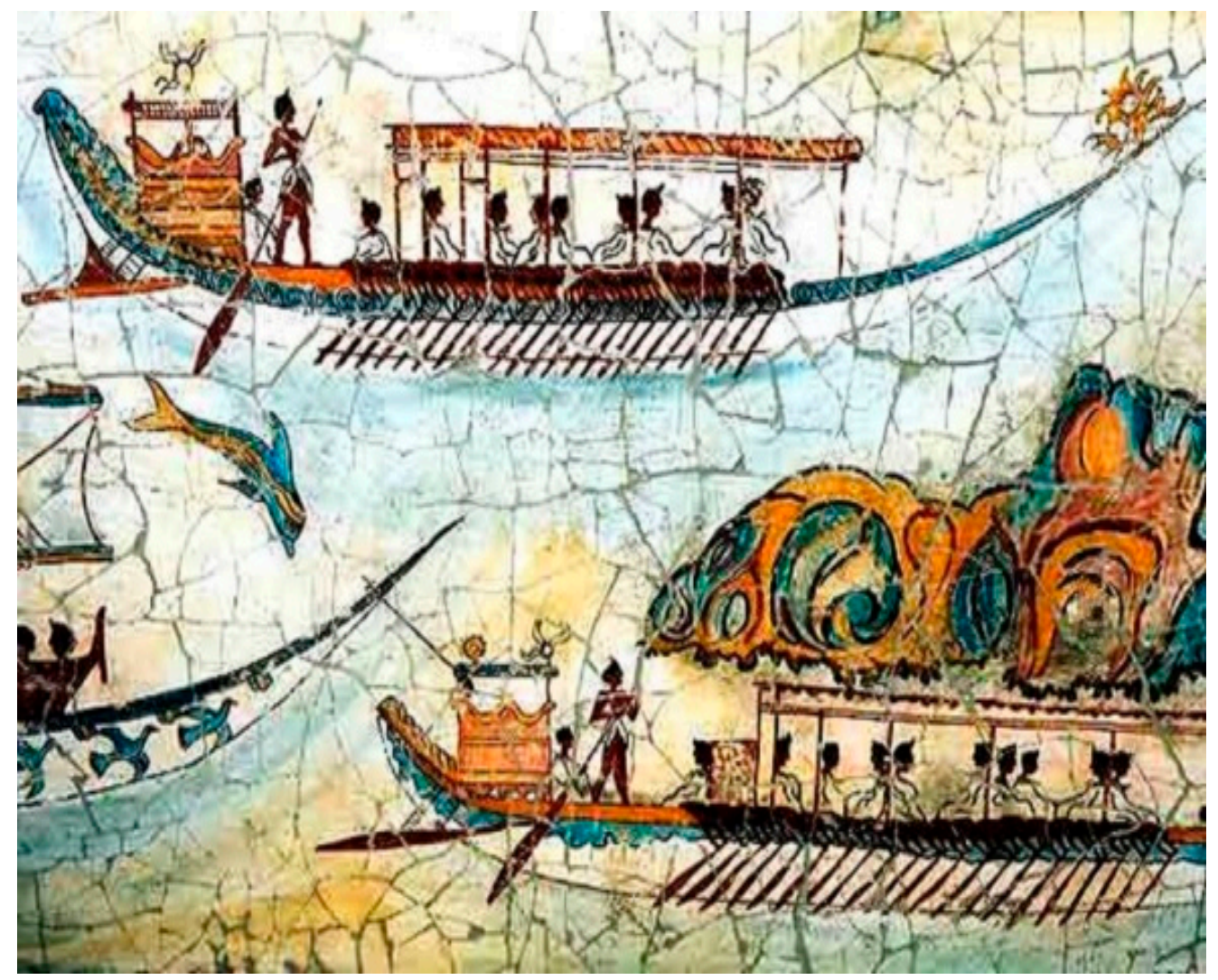

(a)

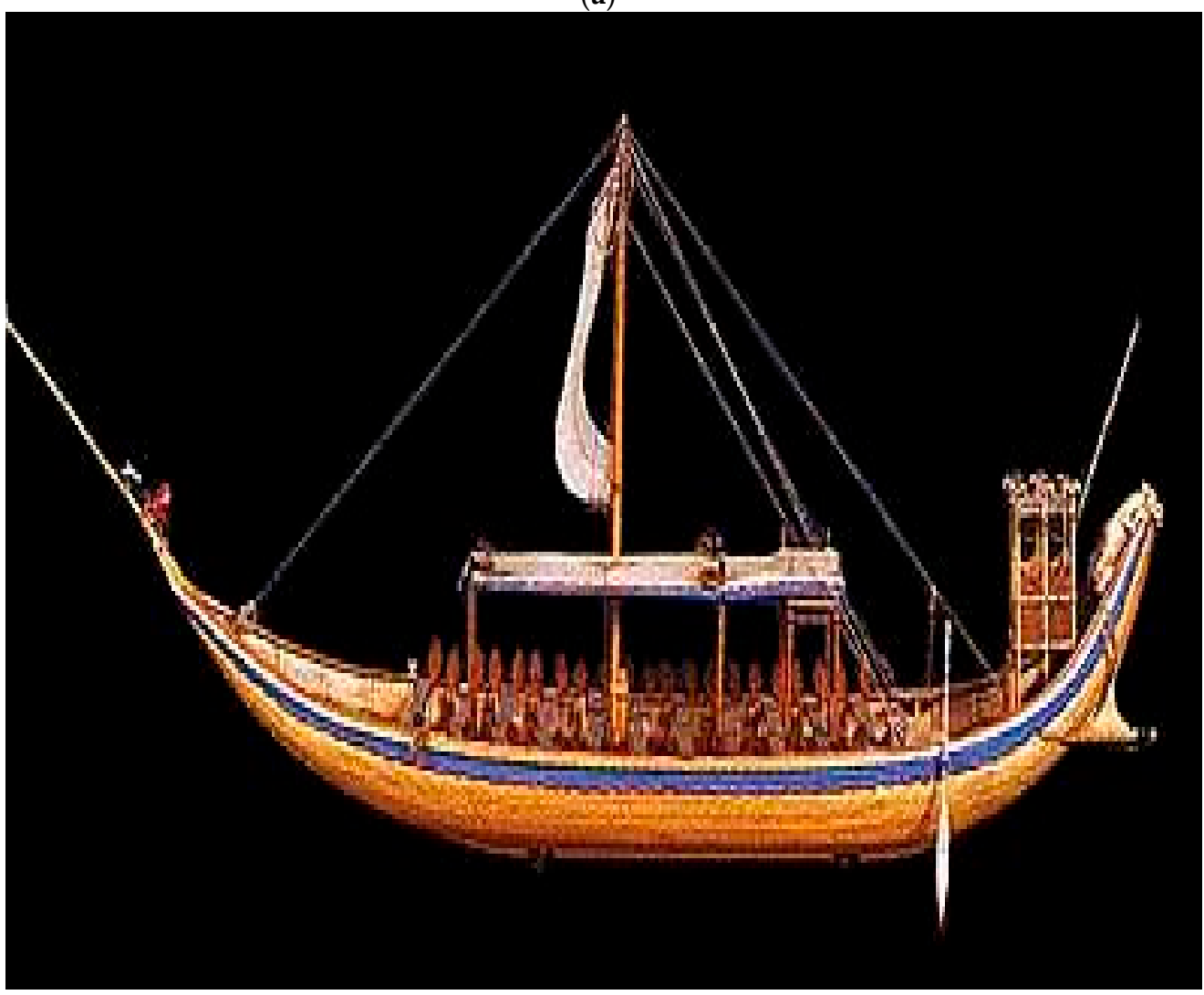

(b)

Figure 2. Examples of Minoan ships: (a) paintings of Minoan ships, as parts of Fresco in "Akrotiri", Thera [25] and (b) a potential model of a ship adapted from the Theran Fresco that further provided insights of the reconstruction [26]. 
Additionally, Hirschfeld [24] stated that: "We should not under-estimate how 'joined up' the ancient world was. For instance, the late Bronze Age shipwreck carried a remarkable assortment of international goods from northern Europe, Africa, and Mesopotamia" (Figure 2b). In the late Bronze Age, the ship revealed one of the most interesting assemblages in the Mediterranean, dated late 14th century BC. A sponge diver found it in southwestern Minor Asia in 1982, and it was very similar to the Graeco-Roman vessels of a very later time.

Finally, it is well known that Egyptians and Greeks, especially in Alexandria, where the Alexander the Great has originally founded the Great School. They have a greater risk attitude rather than the people in the main country. Thus, they were more genuine, spontaneous, and instinctive and had greater risk attitudes that led them towards building remarkable hydraulic works and a better understanding of human needs and wishes. Many water systems, including distillation, established by ancient Egyptian and Greek must be considered as potential models and examples for sustainable water techniques for today and the future, not only as historical ideas and items [27-29].

\subsubsection{Ancient Indians and Indus Valley Civilizations}

In ancient India, in 2000 BC, water treatment methods were used [29]. At that time, it was a concept that heating water might purify it, and there was the technology of using sand and gravel filtration, boiling, and filtering of water. The drinking water taste was better after purification [30]. Mainly turbidity was checked at the earliest time. At that time, there was very little knowledge about chemical contaminants and microorganisms. After $1500 \mathrm{BC}$, the principle of coagulation was discovered and was applied using particle settlement of the chemical alum suspended [31].

After $500 \mathrm{BC}$, desalination and water reuse technology serves to augment water supply in coastal urban regions [29]. India has a coastline of nearly $7500 \mathrm{~km}$. The sea bounds nine different states and four union territories on one or more sides. Desalination may offer a considerable part in augmenting the freshwater demands of the nation [30]. This is possible if desalination technology is implemented efficiently both in terms of technology and economics. Further, states such as Andhra Pradesh, Gujarat, and Tamil Nadu have a severe problem of water shortage and high demand. Therefore, it is crucial that India should place more attention on seawater to fulfill the increasing population's water demands [30].

The Indus Valley civilization (ca. 3000-1500 BC) was one of the ancient, largest, and most advanced civilizations globally, which exemplified the nature of the development of science and society in the prehistoric Indian sub-continent. Harappan small communities were developed into urban centers by ca. 2600 BC. These cities include Mohenjo-Daro (Pakistan), Harappa, Ganeriwala, Kalibangan, Dholavira, Rakhigarhi, Rupar, and Lothal (India).

More than 1052 cities were found in the Indus River region and its tributaries. The Indus Valley civilization people were recognized for their obsession with water as they worshipped and prayed to the rivers $[32,33]$.

Agriculture was the chief commercial activity, and a widespread system of reservoirs, canals, wells, and water harvesting methods was established all over the area [32]. The Mohenjo-Daro Great Bath of Indus Valley is called the "earliest public water tank of the ancient world." Dholavira in Bhachau Taluka of Kutch (Gujarat) is an archeological site.

An exceptional feature of Dholavira is the sophisticated water conservation system, consisting of channels and reservoirs. It is the most primitive water conservation system in the world and was entirely constructed of stone. Dholavira had massive reservoirs used to store the rainwater or the water diverted from two adjacent streams.

The people (Indus Valley civilization) had formed urban water and wastewater management systems. The civilization is the first accredited identified dockyard in the world. Indus society was also aware of oceanic calamities such as tsunami [34].

However, there is no recorded technique of desalination noted in Indian literature. Since there were many rivers, civilizations were more likely dependent on fresh/river 
water than on seawater $[35,36]$. The civilization (Indus Valley) shows evidence of sanitation and water supply for public purposes.

\subsubsection{Iran Empire}

The oldest water supply network, including the desalination system in Persian Empire, was found in Chogha Zanbil, which is an ancient Elamite complex in the southwest of Iran (1250 BC) [37-39]. The water supply network was a river-reservoir network where water was diverted from a river (i.e., the Karkheh River) to a big tank (for water storage purposes) through an open ditch with $45 \mathrm{~km}$ length. After desalination and physical treatment, water was ultimately transferred to the other reservoir, which had a volume equal to $350 \mathrm{~m}^{3}[37,40]$. It is worth mentioning that the ancient Pre-Persian civilization of the Elamites ( $c a .2700$ BC to 539 BC) was developed and settled in Khuzestan, an area known for the abundance of its water. Hence, the management of water resources for the Elamites, who lived in a water-rich area, was not a big challenge.

\subsection{Historical Times (ca. 1000 BC-330 AD)}

\subsubsection{Homer Era}

Danais (Danos) and the Argo (Jason) are the earliest longships used in Greece. Previously, people used small round-shaped vessels called Greek strogulla [41]. The ship Argo was constructed (ca.950 BC) after the pattern of the longship known as Danais (Danos), which came into Greece [26].

\subsubsection{Classical and Hellenistic Periods}

Athenians used many trade ships to convey about 150,000 tons/yr of grains. The majority of these ships were ruined unless a few exceptions survived because covered with ground material of the sea. The so-called Kyrenia ship discovered in Cyprus in 1968 is such a case. While there is evidence that Kyrenia ship has been populated before Minoan civilization ca. 3200 BC, it is traditionally accepted that Athens was founded from neighboring areas following the Trojan War. However, a type of that vessel was adopted in the Hellenistic period. It is believed that the Kyrenia ship sailed for 80 years by three generations of a family called (naukleroi) [26]. In addition, numerous experimentation examples in desalination throughout antiquity are known.

Desalination had been adopted early for millennia. Greek seamen boiled seawater to separate freshwater from salt. In principle, all existing water on the planet is recycled (reused). Since the beginning of Classical times, the Ionian philosophers observed that freshwater on the planet is more or less recycled. Very early, the Anaximander (ca. 610-547 BC), identified the hydrological concept of water recycling on the meteorological phenomena [42,43]. Additionally, Hippocrates (ca. 460-370 BC) invented the sieving water practice and the first bag filter, called the "Hippocratic sleeve". The bag's primary purpose was to trap sediments that caused bad taste or odor [32].

Later on, from $322 \mathrm{BC}$ to $384 \mathrm{BC}$, Aristotle recognized the transformation of water phases and the energy needed for this process as he reported that the sun-heated water on the earth and raised it up; in the same way as water heated by using fire (Meteorologica, II.2, 355a 15). He also stated that if the same amount of water in a certain place does not come back every year, all amount abstracted should be resumed (Meteorologica, II.2, 355a 26) [42,44].

Despite what Aristotle (384-322 BC) learned from Plato, his concepts were highly affected by the philosophers of the Ionic time. His dissertation Meteorologica is a good contribution to the description of several hydrometeorological phenomena such as the concepts of the hydrological cycle, the creation of the clouds, and the spatial and temporal landscape varies through the ages so that rivers are shaped and finally disappear (see also $[45,46])$. He also identified by experimentation which salt contained in the water did not evaporate and reported that:

When it turns into steam, saltwater becomes sweet, and the steam, when it condenses, does not form saline again; this I identify by experimentation (Meteorologica II 3; Translated 
by E. W. Webster [9]. These ideas have found prodigious uses in desalination applications of converting seawater into freshwater, which is very important for arid and semi-arid areas. He stated that in the case of fresh water scarcity at sea, seamen boil the seawater in a brazen vessel and close the mouth of the vessel with a sponge to collect what is evaporated. Then they drink fresh water from squeezing the sponge [47-52].

The necessity of producing potable water on board emerged in seawater for a long time, and distant trips were possible. The first written indication about the desalination of seawater via the boiling process is shown in Figure 3. Alexander of Aphrodisias in ca. 200 $\mathrm{AD}$ illustrated this figure and stated that seamen at sea boiled saltwater in a brass vessel and suspended large sponge to absorb evaporated water [6].

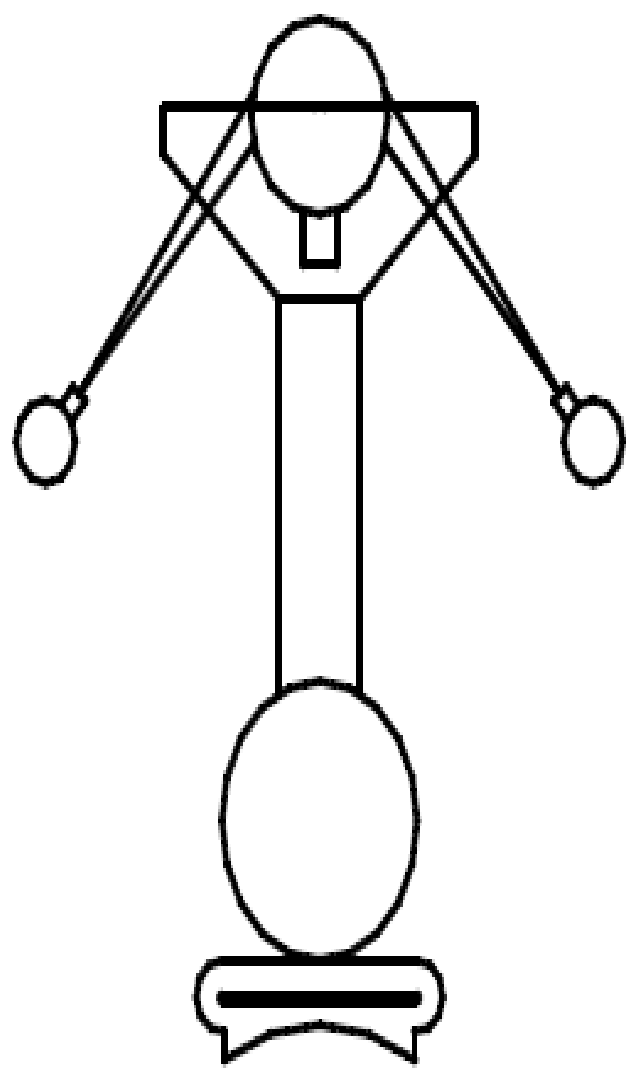

(a)

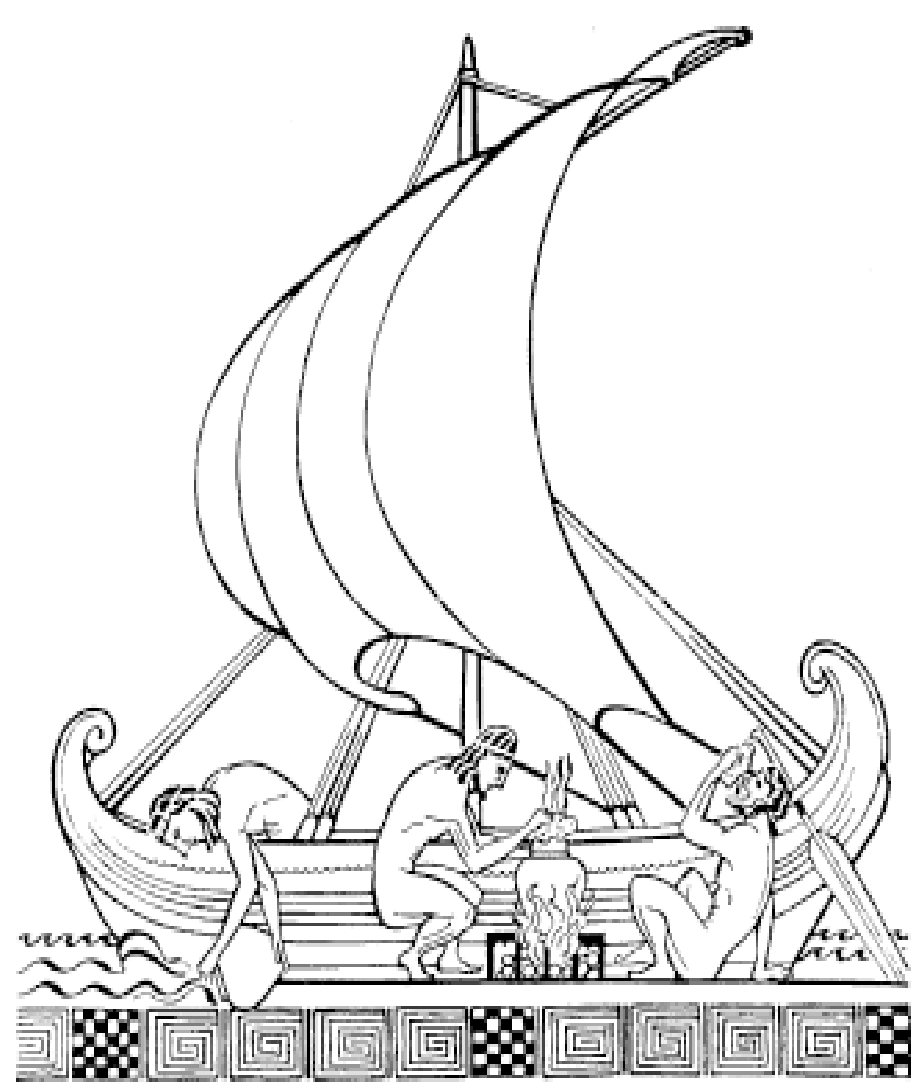

(b)

Figure 3. Desalination in devices in the Hellenistic period: (a) Cleopatra's alembic and (b) sailors producing freshwater with seawater distillation [6].

\subsubsection{Roman Period}

Romans used clay filters to trap the salt, and it was known during that period that water might be purified by heating, using sand and gravel filtration, and straining. Desalination has a long history extending back to the Roman period. There is a religious reference in the Bible (Exodus 15:22-26), which can be considered for desalination [53]. Once Jews went to Marah, Jews could not use potable water. Because the water was bitter, it was called Marah. Jews grumbled against Moses, saying, "What will we drink?" God showed them a log, which they were mixing with the water, and finally, the water that was drinkable became sweet. It should be considered as a miracle instead of scientific evidence.

\subsubsection{Chinese Dynasties}

Although the desalination technology was typically recognized to be formally studied since 1958 by the National Oceanic Bureau in literature [54], the desalination of the sea (salt) water was recorded in China more than 2000 years ago. Both the Classic of Mountains and 
Seas in the Period of the Warring States and the Theory of the Same Year in the Eastern Han Dynasty mentioned that people found that the bamboo mats used for steaming rice would form a thin outer layer after long use. The as-formed thin film had adsorption and ion exchange functions, which could adsorb salt [8]. Lei's Treatise on Preparing Drugs in the Southern Song Dynasty recorded that using an ancient steamer and bamboo mats to cook the kelp (a type of seaweed) could remove salt from the kelp and further prepare herbs for food and medicine [55]. The structures of the steamer and bamboo mats are shown in Figure 4 [56,57]. Moreover, this desalination function by the steamer and bamboo mats was also recorded in the literature of the Song Dynasty [58]. In the Song Dynasty, there is a legend in the Guixin Miscellaneous that when a ship goes to sea for a long voyage, the "sea well" was immersed into the sea, and freshwater can be directly drawn from the "well." Although it may be a legend, it reflects that in the Tang and Song Dynasties, sailors had generated the idea to turn seawater into freshwater [59]. In addition, seawater desalination has a successful experience of direct use in China. On the northern coast of China, farmers used sea ice (which has the nearly same salt concentration as freshwater) to maintain soil moisture. This is the first record of direct use of seawater desalination by freezing [60].

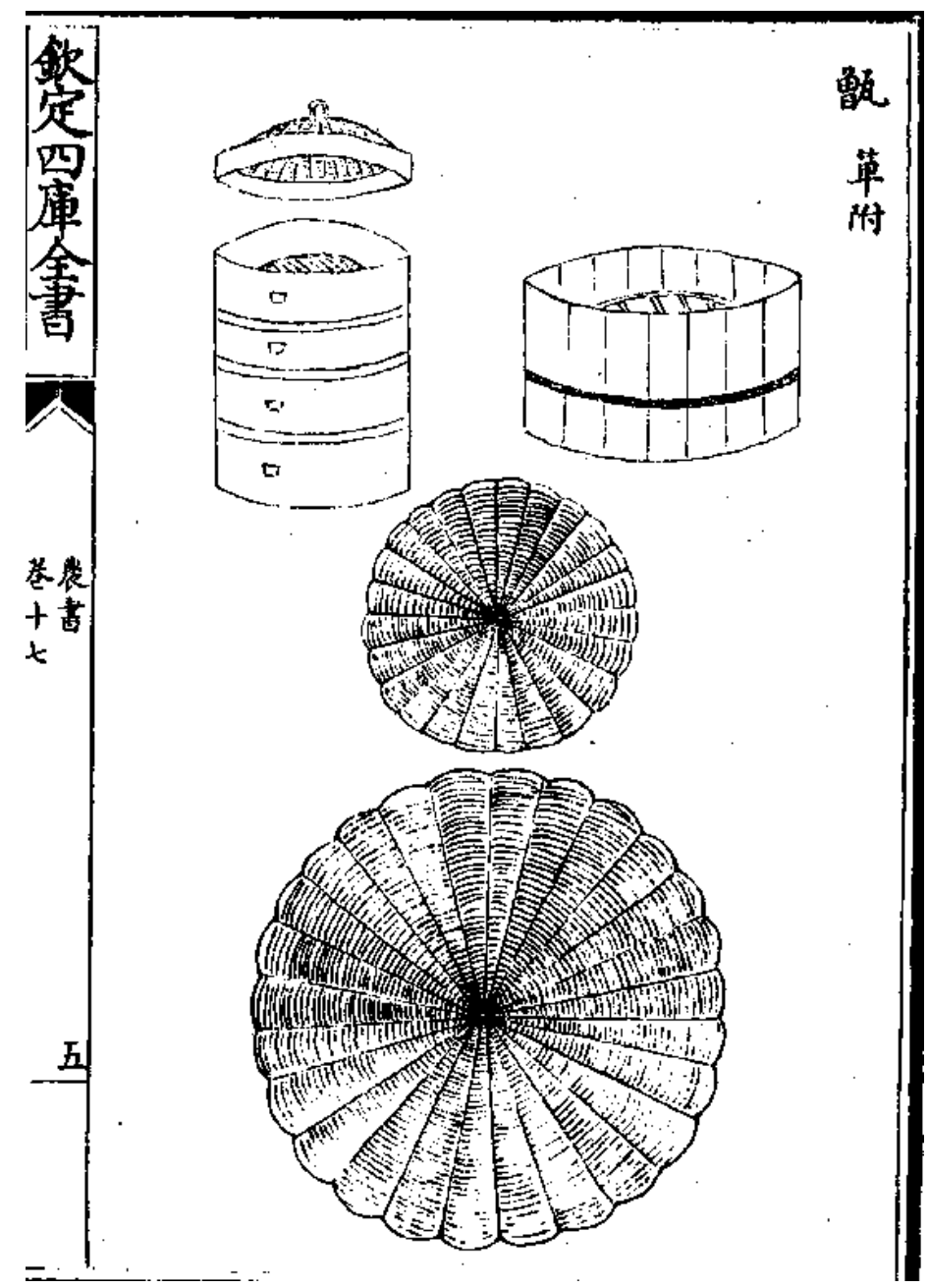

Figure 4. The structure of the steamer and bamboo mats for desalination in the ancient Chinese dynasties [56,57].

\subsection{Medieval Times (ca. 330-1400 AD)}

After the end of the Roman Empire, the future for water treatment and desalination appeared to be uncertain as enemies destroyed many aqueducts, and many were no longer used. Many desalination experiments were performed globally in several places, but it 
was impossible to perform on a large scale in Medieval times [28]. Perhaps the best-known worker in the desalination experiments was Jabir Ibn Hayyan, or Gerber, in the Middle East area, who published an article on distillation in the late 7th century AD [61]. Much of the knowledge and the work done by scholars from early Greek, Persian, Egyptian, and subsequently Muslims such as Abu Mansour Al-Harawi moved to Western Europe via the Moorish conquest of the Iberian Peninsula and the subsequent formation of scientific centers of learning [28,62].

A good experiment was an observation carried by Leonardo da Vinci (in Florence, Italy, in 1452), who understood that distilled water could be produced at a relatively low cost and in large quantities by using a room next to a cooking place [63]. During the Middle times, this work continued in Central Europe on improving the distillation. However, desalination was not necessarily directed towards distillation, which was only recently put into practice. Appropriate technology was developed by early practitioners and is still in use today. Under emergency conditions, the first main desalination plant was probably installed in Tunisia in 1560 [63]. Records show that the first experiment with desalination was probably conducted in 1627 by Sir Francis Bacon. By this experiment, the water was purified as it infiltrated in a sand filter. This technology inspired scientists to continue the methodology of using sand filtration practices.

\section{Desalination in Early and Mid-Modern Times (ca. 1400-1850 AD)}

Desalination was primarily a common practice used in ocean-bound ships before the Industrial Revolution, otherwise needed to supply freshwater on board. Thomas Jefferson in the newly formed USA promoted the heat-based approaches going back to the 15th century [12]. In 1662, Sir Richard Hawkins mentioned that he was able to supply his personnel with freshwater by using distillation technology during his travel to the South Seas [64]. However, both inventions were problematic and were not implemented due to scale-up difficulties [63]. No significant developments to the distillation technology of the seawater were achieved from mid-1600 until 1800. Beginning about 1800 , the appearance of steam engines started changing the applied methodology [63]. The need to use pure water sources in boilers was understood by the thermodynamics of steam technology. Thus, it was possible to improve the distilling systems [65]. Additionally, European Colonial expansion in remote areas of the world improved the conditions for further development of water desalination technology [63].

\section{Desalination in Contemporary Times (1850 AD-Present)}

\subsection{India}

The year 1960 marked the beginning of the investigation on desalination in India. A laboratory under Central Salt and Marine Chemical Research Institute (CSMCRI), Bhavnagar (Gujarat), was entrusted with this task. CSMCRI was engaged with the development of technology for salt and marine chemical production from the sea. A solar desalination unit was set up in 1978 to supply potable water to Awania village and Chhachi lighthouse [66]. Later a seawater desalination plant based on multi-stage flash (MSF) was also established by CSMCRI. The institute started electrodialysis (ED) and RO technology to desalinate seawater and continues to date. The Bhabha Atomic Research Centre (BARC), as a component of research on the Nuclear Powered Agro-Industrial Complex, was also engaged in desalination work using large blocks of cheap energy from nuclear power plants [67]. Research on RO was later included in this project. Electrodialysis for desalination was also taken up at around the same time at the Defense Laboratory, Jodhpur [68].

The National Environmental Engineering Research Institute, Nagpur, initiated research and development on membrane processes for effluent treatment. Various academic and research institutions also started basic research on mass transfer in membrane processes [69]. Finally, several private companies working for water treatment implemented RO technology to enhance demineralization and so to produce good quality water from water with moderate salinity of 1000-1500 ppm. The United Nations declared 1981-1990 
as the "International Decade for Water Supply and Sanitation." During this time, the three laboratories that developed $\mathrm{RO}$ and $\mathrm{ED}$ technology began demonstrating the process of supplying potable water from available brackish groundwater sources in villages [70].

\subsection{China}

In contemporary times, China has started lab experiments and technological research related to desalination since 1958. The National Oceanic Bureau in China started to study electrodialysis [71]. Scientists from the Department of the Shipping Industry paid attention to the pressure distillation process and waste heat flash desalination, while the Shandong Institute of the Ocean started to investigate the RO technology. In 1977, a standpipe multi-effect distillation equipment was invented in Dalian with a treatment capacity of $10-12 \mathrm{~m}^{3} / \mathrm{d}$. An electrodialysis seawater desalination site was built in Yongxing in 1981 with a capacity of $200 \mathrm{~m}^{3} / \mathrm{d}$ [8]. The first seawater $\mathrm{RO}$ desalination site was developed in 1997, located in Shengshan [72]. The site was built to fulfill the needs of the drinking water of residents. Furthermore, a seawater $\mathrm{RO}$ desalination plant with a large volume of $103 \mathrm{~m}^{3} / \mathrm{d}$ was constructed on Dachangshan in 1999 [73]. Since then, RO desalination technology began to develop rapidly in China.

\subsection{Other Countries}

Water desalination technologies began to improve using steam engines during contemporary times (very early, ca. 1850) [28]. The development of thermodynamics in steam processes positively affected distillation processes, and thereby, the need for a pure source of water to use in boilers [74].

In 1676, Jim Birkett reported a possible desalination trial by the English navy. An important British patent was published in 1852 for a distillation plant [75]. In the 1950s, the first new desalination plants were established in Saudi Arabia, Kuwait, Bahrain, and Qatar, in which pretreatment of water by large sand filters was used.

Further, with the development of the multiple-effect evaporators, this methodology rapidly showed its potential to improve technology. These types of desalination plants appear in practice significantly during 1850-1900. The US Army in the 1860s purchased three Normandy evaporators, each rated at $26 \mathrm{~m}^{3} / \mathrm{d}$ [76,77]. After 1980, another essential plant with six-effect distillers with a total capacity of 350 tons/d was installed at Suakin for providing freshwater to the British troops [76].

In 1955 the Office of Saline Water was built in the US Department of the Interior. After World War II, Significant research improvement of desalination approaches occurred in the USA.

In 1974, the new Department was merged into the Office of Water Resources Research. In 1961, in the USA, the first desalination plant opened in Freeport, Texas, with the hope of protecting the region after a long drought.

Also, a recorded speech from the White House of President John F. Kennedy described desalination as: "a method which in many ways is more important than any other scientific enterprise in which the USA is now engaged." A desalination study was conducted at different schools in California and related companies, such as the Dow Chemical Company and DuPont [78]. Several investigations focusing on the methods to optimize desalination methods were reported [13]. In 1965, the first desalination plant, which used RO, was established in California (Coalinga desalination plant). After ten years, a new seawater RO desalination plant was established.

Today more than 20,000 desalination plants with a total capacity of over $100 \mathrm{mil}-$ lion $\mathrm{m}^{3} / \mathrm{d}$ are in operation around the planet. Globally, more than 330 million people, underwater scarcity, now obtain water from desalination plants [79]. Additionally, 53\% (54 million $\mathrm{m}^{3} / \mathrm{d}$ ) of the world's desalination capacity is cited in the Middle East and North Africa $[80,81]$. The biggest ones are in Saudi Arabia, Australia, Israel, and the UAE. The world's biggest desalination plant is located in Saudi Arabia (Ras Al Khair), with water scarcity and inexpensive energy costs for applying fossil fuels. It has a capacity of 
1,401,000 $\mathrm{m}^{3} / \mathrm{d}$ [17]. The multi-stage flash, distillation, and $\mathrm{RO}$ technologies are widely used in the world today.

\section{Emerging Trends in Desalination}

The desalination techniques could be separated into two major groups based on their processes, i.e., major and alternative (Figure 5).

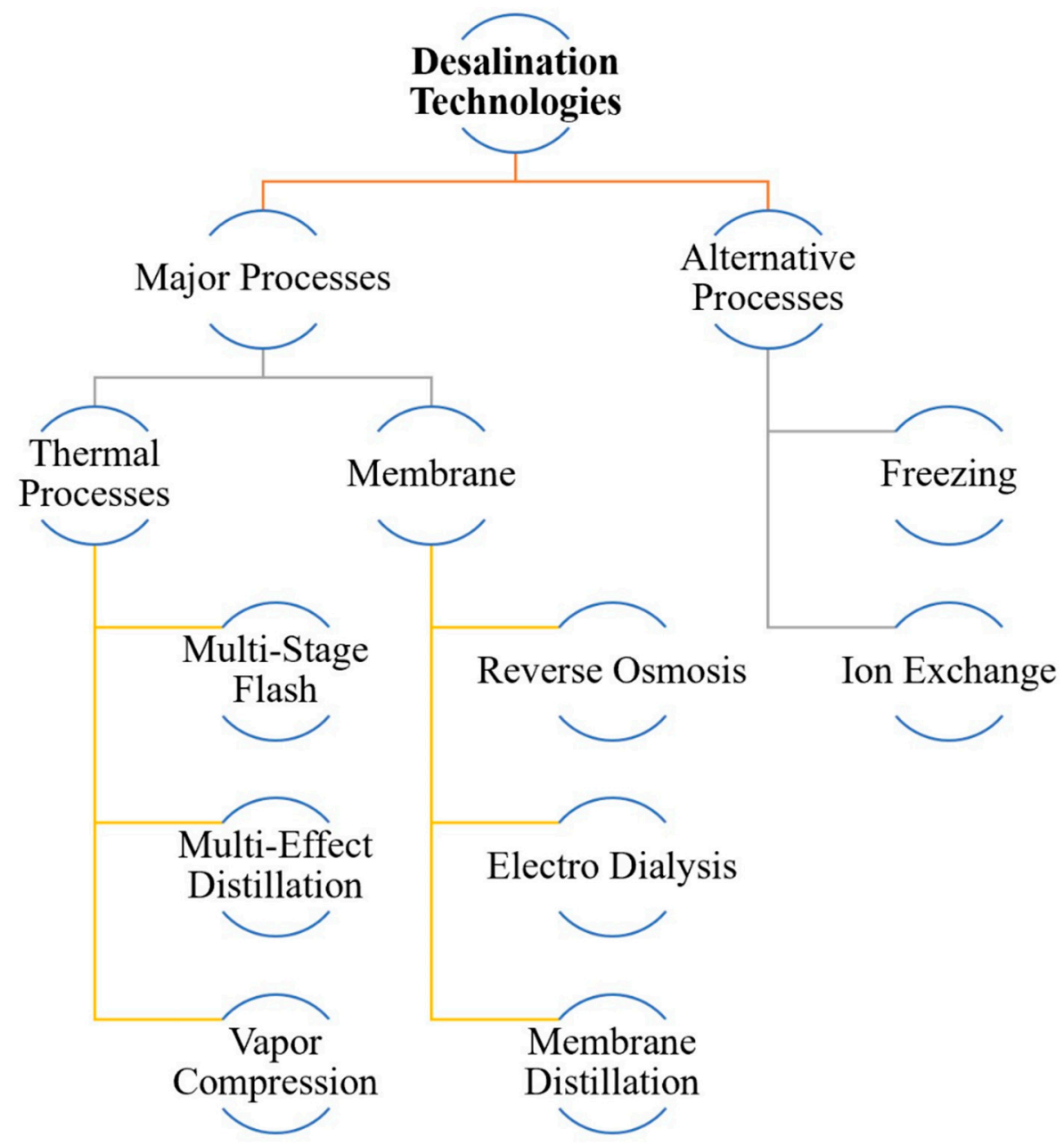

Figure 5. A Schematic diagram of the desalination technologies, updated from [82].

The major processes include thermal processes and membranes. Thermal processes can be further divided into three categories; multi-stage flash, multi-effect distillation, and vapor compression. Whereas $\mathrm{RO}$, reverse osmosis, electrodialysis, and membrane distillation are different types of membrane technology. In recent years, membrane-based desalination has been more popular, replacing the thermal processes. Besides, much attention has been paid to capacitive deionization technology for desalination, owing to porous carbon electrodes with greater ion sorption capacities [81]. It is worth mentioning that the alternative technologies of freezing and ion exchange are not widely adopted yet, although freezing desalination is scientifically interesting [82,83]. The freezing desalination process proceeds with several steps, namely crystallization (production of ice), brine draining, sweating, and melting of the ice. A single freezing desalination process performed with Rabat seawater produced freshwater with a salinity level that meets the drinking water standard [84].

Today, RO desalination plants have been built and are in operation in some regions of the world, especially for water supply in areas under water scarcity. These plants require minimal energy consumption, part of which can be covered by renewable energy sources, 
such as air turbines and solar panels. The plants minimize the burden to the local energy networks and the environment [85]. More efficient process designs also help enhance energy efficiency (Table 1). In combination with pressure retarded osmosis, membrane distillation demonstrated the successful recovery and utilization of hardly recoverable thermal energy for a heat engine [86]. In the forward osmosis (FO) process, the energy required for the product (clean water) recovery from a draw solution is substantial, and consequently, the FO is unlikely to outperform the RO in energy efficiency; however, there is a potential in treating the feed water, which has high fouling propensity $[87,88]$.

Table 1. Different water resources for desalination, the ranges of Total Dissolved Solids (TDS), and the minimum energy for separation (adapted from [88]).

\begin{tabular}{ccc}
\hline Water Source & TDS (mg/L) & $\begin{array}{c}\text { Minimum Energy Required } \\
\text { for Separation (kWh/m } \mathbf{m}^{*} \text { * }\end{array}$ \\
\hline Seawater & 15,000 to 50,000 & 0.67 \\
Brackish water & 1500 to 15,000 & 0.17 \\
River water & 500 to 3000 & 0.04 \\
Domestic & $<500$ & $<0.01$ \\
Wastewater (untreated) & 250 to 1000 & 0.01 \\
Wastewater (treated domestic) & 500 to 700 & 0.01 \\
\hline
\end{tabular}

* Minimum energy has been calculated based on average TDS.

RO desalination plants have limitations in spatial requirements but could be easily adapted to the variations in productivity. The manufacturing process is relatively simple. It necessitates the flexibility of $\mathrm{RO}$ installations being adapted to the water demand variability with small footprints.

Also, the cost of water production needs to be kept as low as possible, even though it remains higher than the other processes. However, it is less expensive than the cost needed for drinking water transportation. Technological progress in desalination is expected to cut down the cost of water production by $20 \%$ within 5 years and by $\sim 60 \%$ in the next 20 years (see Table 2), making the $\mathrm{RO}$ more viable and cost-effective for potable water production [89].

Table 2. Variations of costs for medium-size and large-size desalination projects (adapted from [89]).

\begin{tabular}{cccc}
\hline $\begin{array}{c}\text { Parameters of Best-in-Class } \\
\text { Desalination Plants }\end{array}$ & $\mathbf{2 0 1 6}$ & Within $\mathbf{5}$ Years & Within 20 Years \\
\hline Costs of water from sea water $\left(\mathrm{USD} / \mathrm{m}^{3}\right)$ & 0.8 to 1.2 & 0.6 to 1.0 & 0.3 to 0.5 \\
Costs of construction $(\mathrm{USD} / \mathrm{MLD})$ & 1.2 to 2.2 & 1.0 to 1.8 & 0.5 to 0.9 \\
Electrical energy use $\left(\mathrm{kWh} / \mathrm{m}^{3}\right)$ & 3.5 to 4.0 & 2.8 to 3.2 & 2.1 to 2.4 \\
Membrane productivity $\left(\mathrm{m}^{3} / \mathrm{membrane}\right)$ & 28 to 47 & 35 to 55 & 95 to 120 \\
\hline
\end{tabular}

If fossil-fueled desalination capacities become larger in the Persian Gulf hydraulic supply, it may have environmental consequences that could still be useable for short-term purposes but not for long-term purposes. The intensification of the desalination process in the Persian Gulf has begun over the previous 40 years, creating a harmful effect. The Persian Gulf, which occupies an area of $250,000 \mathrm{~km}^{2}$ with an average depth of $35 \mathrm{~m}$, is more like a salty lake than a typical sea. A few rivers that run to the Persian Gulf have been blocked with dams or redirected somewhere else, increasing the water salinity. Several dozens of the world's largest desalination plants nearby discharge approximately $70 \mathrm{~m}^{3} / \mathrm{d}$ of extremely salty reject brine back into the Persian Gulf. This now makes the Persian Gulf $25 \%$ saltier than average seawater [90]. Considering the population growth and limitations of groundwater resources, the Persian Gulf countries need a doubling of their desalination capacity by 2030 . However, unless the brine disposal is unresolved, the seawater source will be too salty to accommodate the desalination cost while the salinity level keeps rising 
to a peak [91]. As understood from the peak oil theory, the point after which oil extraction declines, peak salt may make desalination unfeasible for the economic and environmental aspects [92]. Carbon emissions overshadow the use of fossil fuels. Likewise, desalination is impacted by peak salt and peak oil [90].

Around $17 \%$ of the world's seawater desalination is commenced from the Mediterranean Sea. In the European coastal countries, the largest desalination producer is Spain, as it produces $7 \%$ of the worldwide desalination volume. The RO process is the main technique adopted in Spain, as it comprises $95 \%$ of all desalination plants [93]. Many important desalination units were established along the coast of the Mediterranean Sea. For example, the Ashkelon desalination plant produces 110 million $\mathrm{m}^{3} / \mathrm{yr}$, with the intake containing $40,679 \mathrm{ppm}$ TDS. The Hadera desalination plant also has a maximum production capacity of $100 \mathrm{~m}^{3} / \mathrm{yr}$ [94]. Moreover, many plants have been constructed on the North Africa coast, where no significant impact of brine has been reported. This could be due to the relatively large sea area and abundant rain compared to the precipitation in the Mediterranean Sea, ranging from 50 to $250 \mathrm{~mm} / \mathrm{yr}$, where the highest precipitation is only observed in the mountainous coastal areas [95].

The Red Sea region is the third-largest in seawater desalination as it produces $14 \%$ of the global desalination volume [93]. There are several desalination plants in Saudi Arabia, such as those at Yanbu, Jeddah, and Jizan. In Egypt, there are many desalination plants in Savaga and Hurgada cities. No river water flows into the Red Sea so that there is no surface water runoff. The Bab el Mandab strait switches water between the Red Sea and the Gulf of Aden. With extremely low rainfalls ( $\sim 60-100 \mathrm{~mm} /$ year with a corresponding volume of $\sim 233,000 \mathrm{~km}^{3}$ ) over the Red Sea and its coasts, the time required for water renewal in the Red Sea is estimated to be 20 years [94]. Accordingly, negative impacts of brine disposal are expected to be more significant in the Red Sea than in the Mediterranean Sea.

\section{Discussions and Remarks}

Seawater intrusion is among the primary groundwater contamination processes in coastal areas, where saline water is moving moves towards or mixing with freshwater aquifers $[96,97]$. When the extreme freshwater abstraction from a coastal aquifer surpasses the natural recharge of freshwater from surface water, salty water is drawn into the aquifer. Thus, seawater intrusion is a major issue in many continents, such as European, north, and south Mediterranean coastal areas.

Lastly, seawater intrusion has become an essential issue in North Africa and Middle East (especially Saudi Arabia, UAE, Israel, Italy, Spain, Greece, Malta, and Cyprus), the USA, and Turkey. Several research studies on seawater intrusion in coastal areas have been conducted. For instance, Felisa et al. [98] simulated seawater intrusion along the Adriatic coast of Emilia-Romagna in Italy.

Mansour et al. [99] and Baba et al. [100] modeled seawater intrusion in the western coast of Turkey. Karahanoglu and Doyuran [101] used the finite element model of seawater intrusion in the coastal aquifer in Turkey. Kallioras et al. [102] reported a conceptual model for the appropriate management of a coastal aquifer in Greece. Qahman and Larabi [103] used a numerical model to assess seawater intrusion in Gaza, Palestine. Sherif et al. [104] used the simulation model of seawater intrusion in the coastal areas of Wadi Ham, UAE, and studied and analyzed the outcomes of various pumping scenarios. Gopinath et al. [105] reported a numerical model for the coastal aquifer of Tamilnadu, India, and Lin et al. [106] used the variable-density groundwater flow to assess the seawater intrusion in the Gulf Coast Aquifer in Alabama, USA. Cobaner et al. [107] developed a model to evaluate seawater intrusion and calculate the effects of pumping quantity on seawater intrusion in the Silifke-Goksu Deltaic plain in Turkey. Sarsak and Almasri [108] monitored seawater intrusion into the coastal region in the Gaza Strip of Palestine. Allow [109] modeled both an underground structure and re-injection well in the coastal plain of the Damsarkho (Latakia), Syria. Abd-Elhamid and Javadi [110] evaluated cost-efficient processes to control 
the seawater intrusion in an aquifer by desalinating the abstracted brackish water and recharging back the aquifer by-product of the desalination process (i.e., brine).

In addition, many studies were conducted in different regions of the world on seawater intrusions [111-114]. These studies showed that the mismanagement of the coastal aquifers resulted in an uncontrolled saltwater intrusion. All these results indicate that many coastal areas have been affected by seawater intrusion processes.

Desalination has changed into a viable alternative water supply for the past three decades due to increasing water scarcity [115]). About $1 \%$ of the world's supplied desalination water for drinking purposes has rapidly grown. Desalination is still evolving in India [116]. India has reported a sudden surge in the capacity of saline water desalination plants from 2006 to 2013 (Figure 6). In India, mainly thermal and membrane processes techniques are applied for desalination.

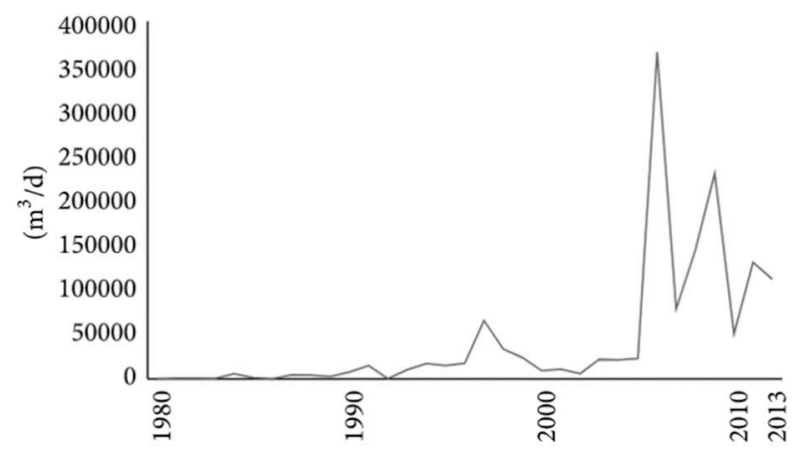

Figure 6. Variations of the capacity of plants for saline water desalination in India [35].

The division of the desalination plants presently working in India with the highest capacity of $44-45 \%$ is shown in Figure 7 . The capacity of most desalination plants is up to $10,000 \mathrm{~m}^{3} / \mathrm{d}$. These plants are used for augmenting agricultural and industrial water use. Two states (Gujarat and Tamil Nadu) are the main desalination centers due to scarcity of water availability, fewer groundwater sources, and high demand [30]. Similarly, desalination technology is used in the coastal areas of other states (Karnataka, Maharashtra, West Bengal, and Andhra Pradesh). In modern times, advances in desalination technology (seawater RO membranes) are fast, productive, and cheaper. Recent studies have shown that desalination is one of the most capable methods employed proficiently to fulfill water demand in India [33]. Low capital cost methods like forwarding osmosis act as an incentive. However, the deficiency of skilled personnel proves to be an impediment, and thus, there is still time before this method verifies to be a significant player in India. It has been estimated that during 2021-2026, desalination systems are projected to observe considerable development in India, especially in the municipal sector. In many regions, municipalities have taken responsibility for treating seawater and provide clean drinking water to people. Two desalination plants were set up by Metrowater at Minjur (150 million liters) and Nemmeli in Chennai with a capacity of 400 million L [117].

The market for desalination systems in India has been anticipated to increase at a Compound Annual Growth Rate (CAGR) of 3\% from 2021 to 2026. The significant element prompting the expansion of desalination systems is the increasing difference between water supply and demand in the nation. Furthermore, the increase in population has again raised the demand for clean water supply, and subsequently, it is predicted to enhance the growth of the desalination systems. However, the rising environmental considerations regarding the operation of desalination systems are thought to curb the rapid growth during this period. The detail of integrated water resource management by desalination and recycling of water is illustrated in Figure 8. The desalination and Water Purification Technologies in India are depicted in Figure 9, which shows the desalination plants and transfer of desalination technology in India at different places in different states [117]. 


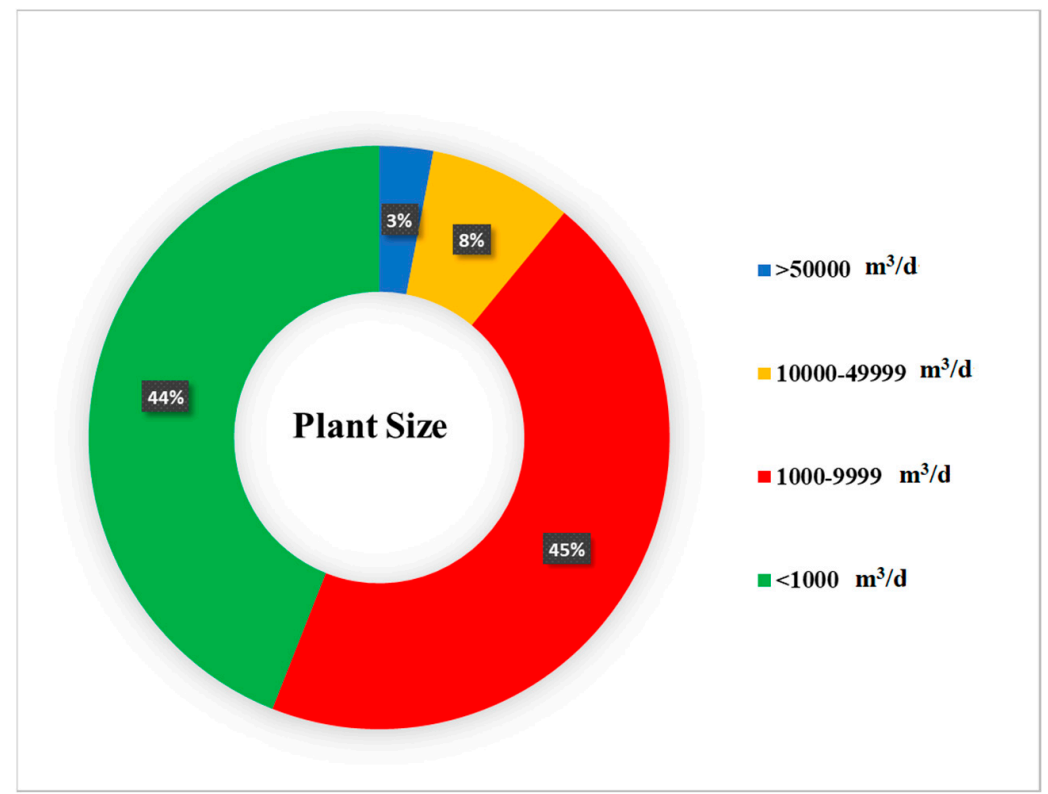

Figure 7. Plant size breakup in India from 2012 to 2013 [35].

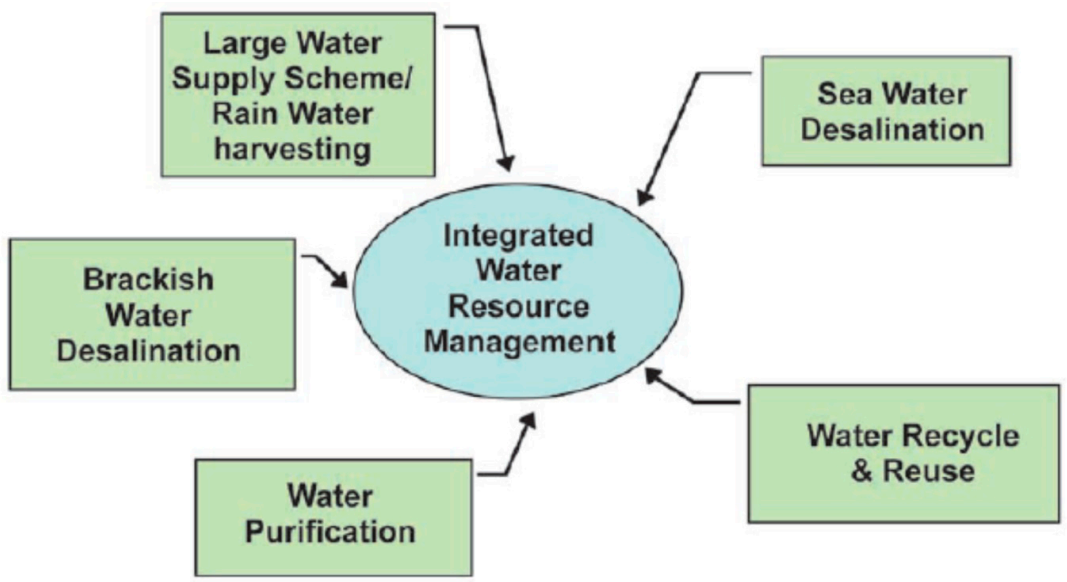

Figure 8. Integrated water resource management through desalination and recycle and reuse of water.

The advances in membrane technology are contributing to desalination processes. Researchers have taken a step toward developing a cost-effective desalination membrane that could provide clean water for drinking and irrigation.

They collaborated with DuPont Water Solutions to look at the nanostructure of membranes to better understand why desalination is still such an enigmatic science $[118,119]$.

Their findings were published recently in the Science journal. RO and nanofiltration (NF) are currently the leading seawater desalination solutions. They contributed mainly to the energy-efficient process, resulting in a low investment cost and low operational cost.

Various membrane techniques and their general characteristics in their applications for water treatment and desalination are shown in Table 3. Desalination is a technology with a wide range of applications in areas with low water availability, contributing to reducing water use and sometimes to mitigate conflicts in local or national areas [120]. The science and experience available in desalination plants have expanded worldwide, especially in membrane operation [121]. However, there are still problems with the environmental footprint, especially in most developing countries [120]. Furthermore, by focusing on smallscale desalination plants and optimizing the technology, the combined use of seawater and freshwater is of main concern for the near future [122]. In addition, the increase of 
desalinated water costs, which have to be incorporated into water supply prices, leads to a rise in the water price of regular water.

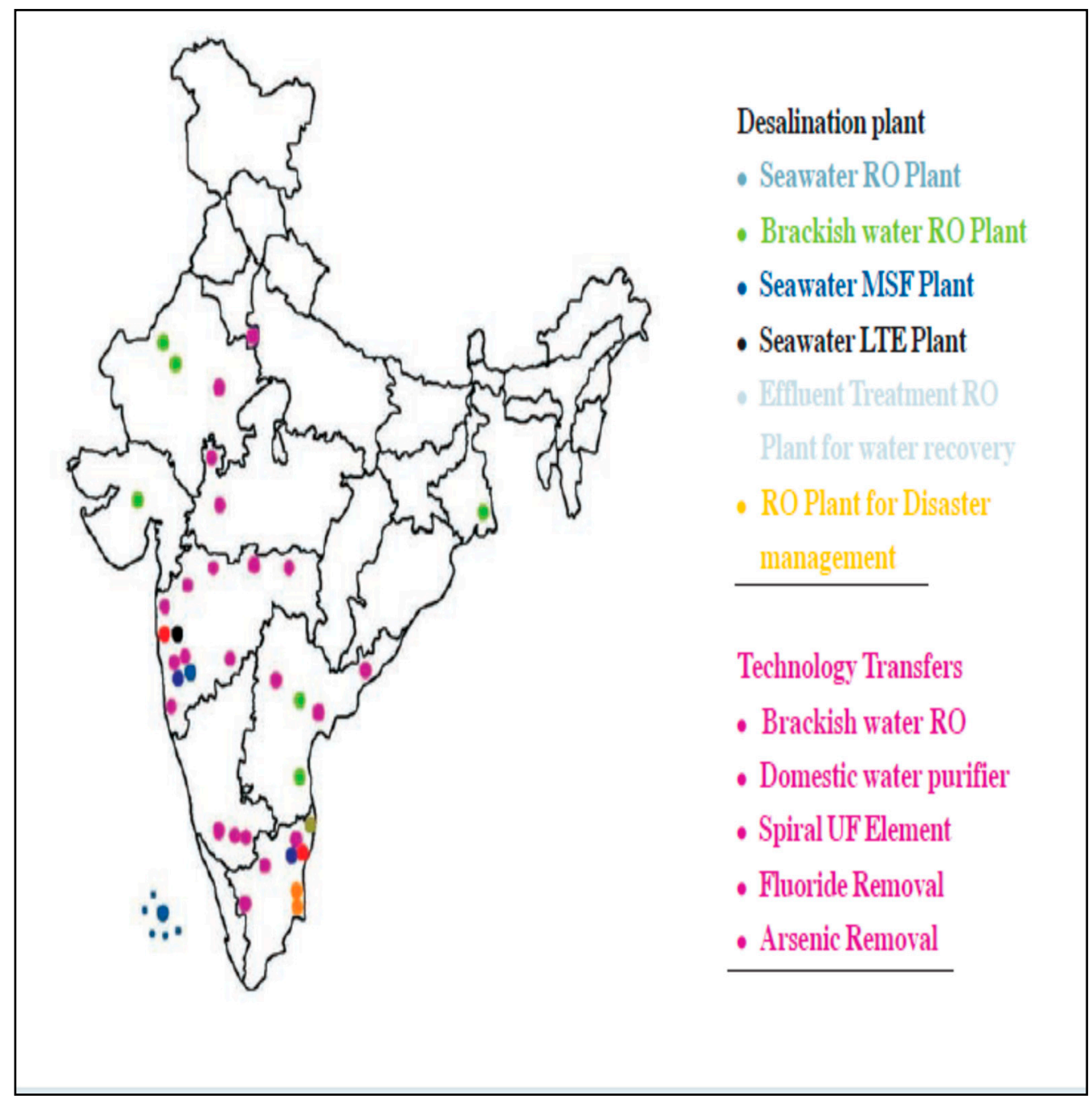

Figure 9. Desalination and water purification technologies by Department of Atomic Energy (as of June 2010).

Table 3. Specific characteristics of membrane techniques for water treatment and desalination (adapted from [119]).

\begin{tabular}{|c|c|c|c|c|}
\hline Membrane Type & Particle Capture Size & $\begin{array}{c}\text { Typical Contaminants } \\
\text { Removed }\end{array}$ & $\begin{array}{l}\text { Typical Operation } \\
\text { Pressure Ranges }\end{array}$ & Key Applications \\
\hline Microfiltration & $0.1-10 \mu \mathrm{m}$ & $\begin{array}{l}\text { Suspended solids, bacteria, } \\
\text { and protozoa }\end{array}$ & $0.1-2$ bar & $\begin{array}{l}\text { Water treatment plants, } \\
\text { pretreatment in desalination } \\
\text { plants, the preparation of sterile } \\
\text { water for industries, such as } \\
\text { pharmaceuticals, etc. }\end{array}$ \\
\hline Ultrafiltration & ca. $0.003-0.1 \mu \mathrm{m}$ & $\begin{array}{c}\text { Colloids, proteins, } \\
\text { polysaccharides, most bacteria, } \\
\text { viruses (partially) }\end{array}$ & $\begin{array}{l}1-5 \text { bar (cross-flow) } \\
0.2-0.3 \text { bar (dead-end }\end{array}$ & $\begin{array}{l}\text { Drinking water treatment, the } \\
\text { pretreatment process in } \\
\text { desalination, and membrane } \\
\text { bioreactors }\end{array}$ \\
\hline Nanofiltration & ca. $0.001 \mu \mathrm{m}$ & $\begin{array}{c}\text { Viruses, natural organic matter, } \\
\text { multivalent ions (including } \\
\text { hardness in water) }\end{array}$ & $5-20$ bar & $\begin{array}{c}\text { Treatment of fresh, process and } \\
\text { wastewaters }\end{array}$ \\
\hline Reverse osmosis & ca. $0.001 \mu \mathrm{m}$ & $\begin{array}{l}\text { Almost all impurities, } \\
\text { including monovalent ions }\end{array}$ & 10-100 bar & $\begin{array}{c}\text { Treatment of fresh, process and } \\
\text { wastewaters, desalination of } \\
\text { seawater }\end{array}$ \\
\hline
\end{tabular}


Desalination technology is developing very fast and becoming a critical component for ensuring water resources sustainability worldwide. The capacity of the plants and the quality of the raw water used are important for the cost of the freshwater produced. Additionally, several other innovations should be considered for reducing power consumption and sustainability [123]. The future of that technique appears to be bright, and it is also highly expected to play a crucial role in the world facing the resource-limited future. Globally, the installed capacity for seawater desalination and brackish water is over 100 million $\mathrm{m}^{3} / \mathrm{d}$ and has grown rapidly over the last 30 years (Figure 10).

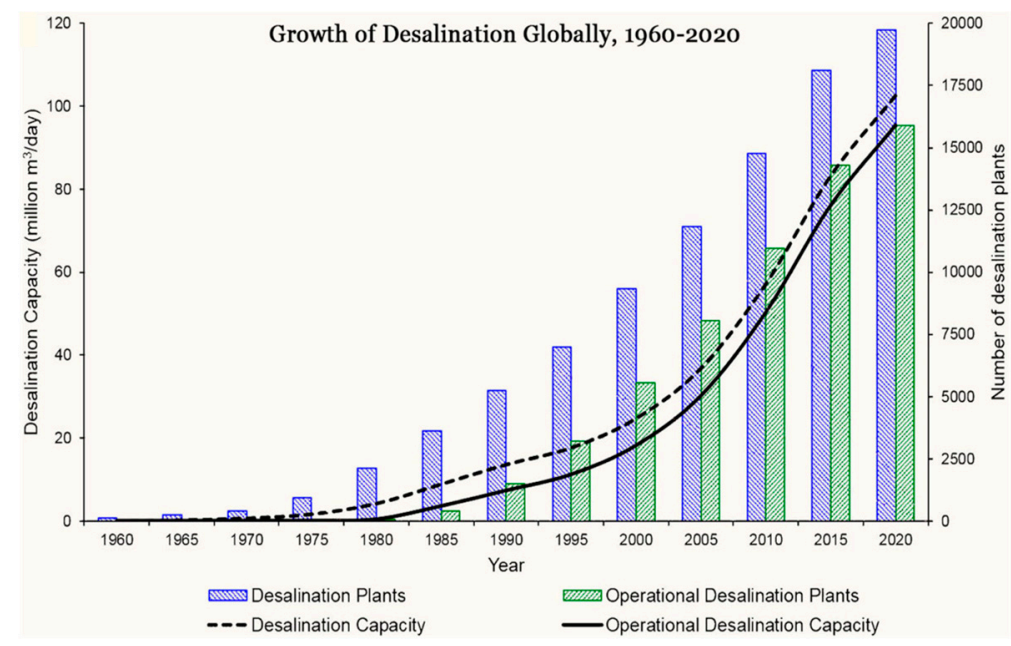

Figure 10. Variations of desalination across the world in the last three decades [124].

Desalination technology will provide an option to alleviate water scarcity, particularly in industrial and coastal areas. About 680 million people live in coastal areas under very low elevations, which is estimated to increase to 1 billion by 2050. Additionally, nearly 65 million people live in developing states of small islands, and 2.4 billion people live in areas within the $100 \mathrm{~km}$ distance from the coast [80]. Most of the areas of groundwater scarcity along or close to the coasts are expected to use seawater as an alternative source for domestic, agricultural, or industrial uses. There is significant progress in desalination today, and it is mainly used for water supply in many areas worldwide. The costs of processing saltwater for drinking water have been reduced, further lowered using brackish water [79]. This can also eliminate environmental issues of brackish water. UNESCO [124] estimates that today around 2.2 billion people worldwide live without access to freshwater. It is estimated that up to 5.7 billion people may be living in 2050 in areas with scarce water for at least one month per year. With seawater and brackish producing up $97.50 \%$ of the world's water resources, low energy requirements will be vital to providing sufficient levels of good-quality drinking water for a growing population. Increasing water requests and deteriorating environmental conditions have continuously stressed the need for new technologies to optimize resources and desalination technology management, treatment, and converting sea or brackish water into potable water. Internet of Things (IoT) allows us to optimize sensors, desalination plants, and other related tools to improve the quality and quantity of desalination and water treatment [125].

\section{Epilogue}

The layman typically considers desalination to be relatively modern water technology, which has been in practice in the contemporary time. However, it has a long and rich history, and many problems faced by the early discoveries are valid today. Many in the desalination field are looking backward from time to time, not only for the practice and experience but also for discovering inventions of professional ancestors [76]. By studying ancient civilizations, we study ourselves, and we learn from the past. The rapid increase of population, urbanization, and climate variability have severely reduced existing 
water resources, including potable water. Furthermore, the availability of freshwater in urban regions has become scarce, if not impossible. Thus, new techniques such as water desalination and direct potable reuse of treated municipal wastewater should be implemented $[42,126]$. Desalination, particularly in coastal areas, is one of the most cost-efficient water technologies, especially in coastal regions that ensure the long-term sustainability of water supplies. Throughout history, civilizations have experimented, with success, to treat salty water and used it for drinking and agriculture. Seawater desalination was applied many centuries ago on ships to produce freshwater through evaporation and condenses of seawater. By the beginning of the 20th century, the first probably big industrial desalination plants producing about $75 \mathrm{~m}^{3}$ water/d were built in 1912 in Egypt with a 6-stage Multiple Effects Evaporator. Thereafter, commercial seawater distillation plants were implemented in the late 1950s, which initially were dependent on industrial evaporators and the distillation plants constructed during World War on the shipboards. At present, desalination technologies of both the sea and brackish water for water supply and irrigation purposes in arid and semi-arid areas seem to be promising technologies. Indeed, desalination technology is already an alternative as the water is produced at a lower price mainly due to the improvement of membranes and significantly reducing the energy requirements, particularly when the process is powered by renewable energy resources [85]. In addition, it should be referred that the combination of desalination and renewable energy resources in autonomous systems in coastal areas is a unique solution for isolated regions with poor and limited local energy supply sources. Decentralization is a necessity for increasing the number of plants. However, with decentralization, the capacity of the plants will be decreased. New developing technologies that are now being implemented will induce advanced and conventional technologies. Such technologies could be created by combining advanced desalination and water reuse in attractive megacities [127]. In addition, new scientific breakthroughs will help to better understand the importance of criteria in both water and treated wastewater and their effects on human health [128]. New guidelines and regulations will need to be developed to understand the reflection of these enhanced biological and chemical processes. To meet future challenges effectively, water reuse and treatment, especially in megacities, a singular water concept should be embraced [42]. The increase in population and especially urbanization has created water scarcity conditions, which are influencing desalination and wastewater reclamation processes. On the other hand, with an increase in the social perception of water and an emerging water-reuse and desalination market, climate change has adverted effects on water production processes [129]. It must be recognized that withdrawing water from inland regions, transporting and treating it to urban coastal regions, using once, and discharging it to the sea is not sustainable. We must think about the combination of desalination and wastewater differently (i.e., both as sources of water), and we must use a unified vocabulary. The major points that emerge from this comprehensive review are the following:

- Lastly, the RO desalination costs have been significantly reduced, especially during the previous 15 years. Further improvement of RO membranes and the use of alternative energy sources will more reduce the cost;

- The desalination membrane approach will continue to develop to become more costeffective and environmentally friendly;

- Water demand and low water availability will continue to utilize desalination more sustainably;

- Science and technology should be further developed to modify the disinfection and decontamination of water. In addition, more efforts are required for water supplies by efficiently desalinating seawater and brackish water and the safe reuse of wastewater. In the developed world, there is a potential of applying new technologies in terms of water management, internationally and mainly in the coastal areas, provided that there is a possibility for investment in relative sectors. Additionally, emphasis should be given to the green criteria of desalination [85]; 
- In some developing countries with abundant seawater resources but lack freshwater resources (e.g., China and other developing countries), the desalination plant should be constructed based on the economic and social development level of the coastal regions. Therefore, efficient and cost-effective desalination technologies are highly desirable for the regions in developing countries;

- Desalination techniques could solve the limited water availability in coastal regions and may lead to the best environmental, economic, and social results for the coastal area and the local communities contributing substantially to comprehensive and worth-living growth;

- Maximum current desalination methods are presently areas of dynamic research, performed continuously to refine the technologies, decrease the cost, and increase efficacy;

- Finally, the use of brackish water and the combined water reuse, especially in the coastal areas and the areas under water scarcity, will increase the use of desalinated water.

- Lastly, the idea of separating salt from water is an ancient practice, dating from the time when salt, not water, was a precious commodity. Appendix A shows a timeline in terms of the historical improvement of desalination technologies.

Author Contributions: A.N.A. had the original idea, prepared the original draft of the manuscript, and revised and edited it. M.V., K.-H.C., A.T.A., A.B., R.K., G.S.T. and Z.W. revised and edited the manuscript. All authors have read and agreed to the published version of the manuscript.

Funding: This research received no external funding.

Institutional Review Board Statement: Not applicable.

Informed Consent Statement: Not applicable.

Data Availability Statement: Not applicable.

Acknowledgments: We greatly acknowledge Cynthia Lynn Hann for her considerable contribution of English grammatical and fluidity improvement in the development of this paper. The authors appreciate the two reviewers for their helpful and constructive comments, which helped to improve the quality of this manuscript.

Conflicts of Interest: The authors declare no conflict of interest.

\section{Appendix A}

Table A1. A timeline in terms of the historical improvement of desalination technologies.

\begin{tabular}{|c|c|c|}
\hline Period (ca. Years) & Achievements & Comments \\
\hline 3200-1100 BC & $\begin{array}{l}\text { The first indication for the application of seawater desalination } \\
\text { is known to be by Minoan sailors using distillation. }\end{array}$ & In Mediterranean \\
\hline $1250 \mathrm{BC}$ & $\begin{array}{l}\text { The oldest water supply network, including desalination, was } \\
\text { during the Persian Empire. }\end{array}$ & In Chogha Zanbil, southwest of Iran. \\
\hline $610-547$ BC & $\begin{array}{l}\text {... rains are generated from the evaporation (atmis) which is sent up } \\
\text { from the earth toward under the sun (Anaximander, ca. 610-546) }\end{array}$ & $\begin{array}{c}\text { In Miletus. } \\
\text { Hippolytus, Ref. I6, 1-7-D.559 } 109 \text { W.10. }\end{array}$ \\
\hline $384-322$ BC & $\begin{array}{c}\text {...the sun causes the moisture to rise; that is like what happens when } \\
\text { water is heated by using fire (Aristotle, 384-328 BC) }\end{array}$ & $\begin{array}{c}\text { In Athens } \\
\text { Meteorologica, II.2, 355a } 15\end{array}$ \\
\hline $200 \mathrm{AD}$ & $\begin{array}{c}\text { The Alexander of Aphrodisias said: "sailors at sea boiled seawater } \\
\text { and suspended large sponges from the mouth of a brass vessel to } \\
\text { absorb what is evaporated." }\end{array}$ & $\begin{array}{l}\text { Athens } \\
\text { Kalogirou (2005) }\end{array}$ \\
\hline
\end{tabular}


Table A1. Cont.

\begin{tabular}{|c|c|c|}
\hline Period (ca. Years) & Achievements & Comments \\
\hline 1560 & $\begin{array}{c}\text { The first major land-based desalination plant was constructed } \\
\text { in Tunisia. A guard of hundreds of Spanish soldiers was } \\
\text { besieged through a large number of Turks. It was capable of } \\
\text { producing } 40 \text { barrels of freshwater per day. }\end{array}$ & \\
\hline $1535-1615$ & $\begin{array}{l}\text { Giovanni Battista Della Porta wrote many books in which } \\
\text { several desalination technologies are considered. }\end{array}$ & \\
\hline 1774 & $\begin{array}{c}\text { Malik et al. [130] stated that the Great French chemist Lavoisier } \\
\text { applied large glass lenses mounted on elaborate supporting } \\
\text { structures to concentrate sunlight on the contents of } \\
\text { distillation flasks. }\end{array}$ & \\
\hline 1850 & $\begin{array}{l}\text { The first desalination plants started to appear by using steam } \\
\text { engines to apply thermodynamics to achieve a positive effect } \\
\text { for distilling processes. }\end{array}$ & \\
\hline 1950 & $\begin{array}{l}\text { The first new desalination plants were established in Saudi } \\
\text { Arabia, Kuwait, Bahrain, and Qatar, in which pretreatment of } \\
\text { seawater by sand filtration was applied. }\end{array}$ & \\
\hline 1961 & $\begin{array}{l}\text { The first desalination plant was constructed in the USA } \\
\text { (Freeport, TX, USA) for protecting the region after a relevant } \\
\text { long-time drought. }\end{array}$ & \\
\hline 1960 & $\begin{array}{l}\text { The first large-scale commercial RO desalination plant, in } \\
\text { Coalinga (in Fresno County), in California. }\end{array}$ & It used brackish water \\
\hline 2000 & $\begin{array}{l}\text { After 2000, more than } 2000 \text { plants are operated on the whole } \\
\text { planet. The largest are in Saudi Arabia, Israel, and UAE. }\end{array}$ & \\
\hline 2019 & $\begin{array}{l}\text { In the globe, the biggest plant with a volume of 1,401,000 m³ /d } \\
\text { is in Saudi Arabia (Ras Al Khair). }\end{array}$ & \\
\hline 2020 & $\begin{array}{l}\text { On the whole planet, there are } 22,000 \text { plants in operation. In } \\
\text { Taweelah, UAE, the second largest plant by capacity }(909,200 \\
\mathrm{m}^{3} / \mathrm{d} \text { ) was constructed. The third is in Shuaiba } 3 \text { and was } \\
\text { constructed in Saudi Arabia with a capacity of } 880,000 \mathrm{~m}^{3} / \mathrm{d} \text {. } \\
\text { The fourth is in Sorek, Israel, with a volume of } 624,000 \mathrm{~m}^{3} / \mathrm{d} \text {. } \\
\text { With a volume of } 600,000 \mathrm{~m}^{3} / \mathrm{d} \text {, the fifth plant is in Rabigh } 3 \\
\text { IWP, Saudi Arabia, and the sixth with a capacity of } 591,000 \\
\mathrm{~m}^{3} / \mathrm{d} \text { is in Fujairah } 2 \text { UAE [131]. }\end{array}$ & \\
\hline
\end{tabular}

\section{References}

1. Nair, M.; Kumar, D. Water desalination and challenges: The Middle East perspective: A review. Desalination Water Treat. 2013, 51, 2030-2040. [CrossRef]

2. Angelakis, A.N.; Spyridakis, S.V. Major Urban Water and Wastewater Systems in Minoan Crete, Hellas. Water Sci. Technol. Water Supply 2013, 13, 564-573. [CrossRef]

3. Costa, M. The Climate and History of Algarve-Interactions. Advances in Climate Changes, Global Warming, Biological Problems and Natural Hazards; University of Algarve: Algarve, Portugal, 2010; pp. 70-75.

4. Angelakis, A.N.; Spyridakis, D.S. Water Supply and Wastewater Management Aspects in Ancient Hellas. Water Sci. Technol. Water Supply 2010, 10, 618-628. [CrossRef]

5. Delyannis, A. Introduction to chemical technology. In History of Chemistry and Technology; Britannica: Athens, Greece, 1960; p. 410. (In Greek)

6. Kalogirou, S.A. Seawater desalination using renewable energy sources. Prog. Energy Combust. Sci. 2005, 31, 242-281. [CrossRef]

7. Delyannis, E.; Belessiotis, V. The history of renewable energies for water desalination. Desalination 2000, 128, 147-159.

8. Zhu, S.F.; Xue, L.B.; Xu, Z.D. The development history and an analysis of status quo of desalination at home and abroad. Technol. Water Treat. 2014, 40, 12-23.

9. Webster, E.W., Translator; Meteorologica, Aristotle. In The Works of Aristotle, 3rd ed.; Ross, W.D. (Ed.) Clarendon Press: Oxford, UK, 1931; Volume 3, pp. §358: 16-18, §359: 1-5.

10. Needham, J.; Ping-Yu, H.; Gwei-Djen, L.; Sivin, N. Science and Civilisation in China: Volume 5, Chemistry and Chemical Technology; Cambridge University Press: Cambridge, UK, 1980; p. 60. 
11. Hinkebein, T. Desalination: Limitations and Challenges. National Academy of Sciences. Available online: https://www.ncbi.nlm. nih.gov/books /NBK83737/ (accessed on 3 May 2021).

12. Jefferson, T. Report on Desalination of Sea Water. National Archives. Available online: https://founders.archives.gov/ documents/Jefferson/01-22-02-0296 (accessed on 3 May 2021).

13. Talbot, D. Bankrolling the 10 Breakthrough Technologies: Megascale Desalination. IDE Technologies. Available online: https:/ / web.archive.org/web/20161003210024/http:/ / www.ide-tech.com/blog/publication/bankrolling-10-breakthroughtechnologies-megascale-desalination/ (accessed on 3 May 2021).

14. Garcia-Rodriquez, L. Seawater desalination driven by renewable energies: A review. Desalination 2002, 143, 103-113. [CrossRef]

15. Cooley, H.; Gleick, P.H.; Wolff, G. Desalination, with a Grain of Salt: A California Perspective; Pacific Institute: Oakland, CA, USA, 2006.

16. Singleton, M.; Heiss, G.; Hubler, A. Optimization of ramified absorber networks doing desalination. Phys. Rev. E 2011, 83, 16308. [CrossRef]

17. Koutroulis, E.; Kolokotsa, D. Design optimization of desalination systems power-supplied by PV and W/G energy sources. Desalination 2010, 258, 171. [CrossRef]

18. Cipollina, A.; Micale, G.; Rizzuti, L.; Cipollina, A. (Eds.) Seawater Desalination: Conventional and Renewable Energy Processes; Springer: Berlin/Heidelberg, Germany, 2009; Volume 1.

19. IDA, Media Analytics Ltd. The 20th IDA Worldwide Desalting Plant Inventory; MS Excel Format, Media Analytics Ltd.: Oxford, UK, 2007.

20. Spanakis, S. The Water Supply of Iraklion; The Technical Chamber of Hellas: Iraklion, Greece, 1981; pp. 828-1939. (In Greek)

21. Angelakis, A.N.; Kavoulaki, E.; Dialynas, M.G. Sanitation and stormwater and Wastewater Technologies in Minoan Era. In Evolution of Sanitation and Wastewater Management through the Centuries; Angelakis, A., Rose, J., Eds.; IWA Publishing: London, UK, 2014; Chapter 1; pp. 1-24.

22. Muge, A.; Loukovikas, M. Chronicle 2: Minoan Cretan Thalassocracy. Periplus. Available online: http:/ / peripluscd.wordpress. com/2013/03/04/chronicle-2-minoan-cretan-thalassocracy-2/ (accessed on 3 May 2021).

23. Angelakis, A.N. Urban waste- and stormwater management in Greece: Past, Present and Future. Water Sci. Technol. Water Supply 2017, 17, 1386-1399. [CrossRef]

24. Hirschfeld, E. Grace in the Aegean: The art of the Minoans. In Marxist Theory of Art. Available online: http:/ / marxist-theory-ofart.blogspot.gr/2010/11/grace-in-aegean-art-of-minoans.html (accessed on 7 June 2021).

25. Raban, A. The Thera ships: Another interpretation. Am. J. Archaeol. 1984, 88, 11-19. [CrossRef]

26. Lahanas, M. Ancient Greek Ships. Available online: http://www.hellenicaworld.com/Greece/Technology/en/Ships2.html (accessed on 3 May 2021). (In Greek).

27. EPA. The History of Drinking Water Treatment. Environmental Protection Agency, Office of Water (4606), Fact Sheet EPA-816F-00-006 United States. 2000. Available online: https:/ / www.lenntech.com/history-water-treatment.htm\#ixzz6ZVp9GmkW (accessed on 30 April 2020).

28. Birkett, J.D. A brief illustrated history of desalination: From the bible to 1940. Desalination 1984, 50, 17-52. [CrossRef]

29. Ahmed, A.T.; El Gohary, F.; Tzanakakis, V.; Angelakis, A.N. Egyptian and Greek Water Cultures and Hydro-technologies in Ancient Times. Sustainability 2020, 12, 9760. [CrossRef]

30. Subramaniam, H. Fresh from the Sea; The Hindu: Chennai, India, 2013.

31. Madhusoodhanan, C.G.; Sreeja, K.G.; Eldho, T.I. Climate change impact assessments on the water resources of India under extensive human interventions. Ambio 2016, 45, 725-741. [CrossRef] [PubMed]

32. Nair, K.S. Role of water in the development of civilization in India-A review of ancient literature, traditional practices and beliefs. Int. Assoc. Hydrol. Sci. Publ. 2000, 286, 160-166.

33. Jansen, M. Water supply and sewage disposal at Mohenjo-daro. World Archaeol. 2010, 21, 177-192. [CrossRef]

34. Baba, A.; Tsatsanifos, C.; El Gohary, F.; Palerm, J.; Khan, S.; Mahmoudian, S.A.; Ahmed, A.T.; Tayfur, G.; Dialynas, Y.G.; Angelakis, A.N. Developments in water dams and water harvesting systems throughout history in different civilizations. Int. J. Hydrol. 2018, 2, 150-166. [CrossRef]

35. Mehta, D.; Gupta, L.; Dhingra, R. Forward Osmosis in India: Status and Comparison with Other Desalination Technologies. Int. Sch. Res. Not. 2014, 2014, 1-9. [CrossRef] [PubMed]

36. Khan, B. 1 Chapter 2 Sanitation and Wastewater Technologies in Paragraph/Indus Valley Civilization (ca. 2600-1900 BC); IWA Publisher: London, UK, 2015.

37. Saatsaz, M. A historical investigation on water resources management in Iran. Environ. Dev. Sustain. 2020, 22, 1749-1785. [CrossRef]

38. Semsar Yazdi, A.A.; Askarzadeh, S. A historical review on the Qanāts and historic hydraulic structures of Iran since the first millennium BC. In Proceedings of the International History Seminar on Irrigation and Drainage, Tehran, Iran, 20 May 2007.

39. Sadr, H. National Museum of Iran (Iran-e Bastan). Tavoos Art Quarterly, No. 7. Available online: http://www.tavoosonline.com/ Articles (accessed on 2 May 2017).

40. Sanizadeh, S.K. Novel hydraulic structures and water management in Iran: A historical perspective. In Water Culture and Water Conflict in the Mediterranean Area; El Moujabber, S., Trisorio-Liuzzi, O., Laureano, R., Eds.; Options Méditerranéennes: Mardid, Spain, 2008; Volume 83, pp. 25-43. 
41. Connoly, P. The Legend of Odysseus; Oxford University Press: Oxford, UK, 1986.

42. Angelakis, A.N.; Asano, T.; Bahri, A.; Jimenez, B.E.; Tchobanoglous, G. Water Reuse: From ancient to the modern times and future. Front. Environ. Sci. 2018, 6, 26. [CrossRef]

43. Paranychianakis, N.V.; Salgot, M.; Snyder, S.A.; Angelakis, A.N. Quality Criteria for Recycled Wastewater Effluent in EUCountries: Need for a Uniform Approach. Crit. Rev. Environ. Sci. Technol. 2015, 45, 1409-1468. [CrossRef]

44. Koutsoyiannis, D.; Angelakis, A.N. Hydrologic and Hydraulic Sciences and Technologies in Ancient Greek Times. In The Encyclopedia of Water Science; Stewart, B.A., Howell, T., Eds.; Madison Ave, Markel Dekker Inc.: New York, NY, USA, 2003; pp. 415-417.

45. Koutsoyiannis, D. Water control in the Greek cities. In Water Systems and Urbanization in Africa and beyond Uppsala; University of Uppsala: Uppsala, Sweden, 2012.

46. Koutsoyiannis, D.; Mamassis, N.; Tegos, A. Logical and illogical exegeses of hydrometeorological phenomena in ancient Greece. Water Sci. Technol. Water Supply 2007, 7, 13-22. [CrossRef]

47. Morewood, S. An Essay on the Inventions and Customs of both Ancients and Moderns in the Use of Inebriating Liquors; Spottiswood Publisher: London, UK, 1824. Available online: http:/ / books.google.gr/books?id=os4GAAAAQAAJ (accessed on 3 May 2021).

48. Gaudio, M.T.; Coppola, G.; Zangari, L.; Curcio, S.; Greco, S.; Chakraborty, S. Artificial Intelligence-Based Optimization of Industrial Membrane Processes. Earth Syst. Environ. 2021, 5, 385-398. [CrossRef]

49. Valipour, M.; Bateni, S.M.; Dalezios, N.R.; Almazroui, M.; Heggy, E.; Şen, Z.; Angelakis, A.N. Hydrometeorology: Review of Past, Present and Future Observation Methods; Theodore, V., Hromadka, I.I., Prasada, R., Eds.; Hydrology, IntechOpen Publisher: London, UK, 2020.

50. Angelakis, A.N.; Valipour, M.; Ahmed, A.T.; Tzanakakis, V.; Paranychianakis, N.V.; Krasilnikoff, J.; Drusiani, R.; Mays, L.; El Gohary, F.; Koutsoyiannis, D.; et al. Water conflicts: From ancient to modern times and in the future. Sustainability 2021, $13,4237$. [CrossRef]

51. Valipour, M.; Ahmed, A.T.; Antoniou, G.P.; Sala, R.; Parise, M.; Salgot, M.; Sanaan Bensi, N.; Angelakis, A.N. Sustainability of underground hydro-technologies: From ancient to modern times and toward the future. Sustainability 2020, 12, 8983. [CrossRef]

52. Angelakis, A.N.; Antoniou, G.; Yapijakis, C.; Tchobanoglous, G. History of Hygiene Focusing on the Crucial Role of Water in the Hellenic Asclepieia (i.e., Ancient Hospitals). Water 2020, 12, 754. [CrossRef]

53. Kumar, M.; Culp, T.; Shen, Y. Water Desalination: History, Advances, and Challenges. In Frontiers of Engineering Report on Leading-Edge Engineering; The National Academy Press Pennsylvania State University: Philadelphia, PA, USA, 2017.

54. Zhu, Z.F.; Peng, D.Z.; Wang, H.R. Seawater desalination in China: An overview. J. Water Reuse Desalination 2019, 9, 115-132. [CrossRef]

55. Lei, X.P. Lei's Treatise on Preparing Drugs; Jiangsu Science and Technology Press: Beijing, China, 1985.

56. Ji, Y. General Catalogue Summary of Imperial Book Collections of Four Seriesand; Chung Hwa Book Corporation: Beijing, China, 1997.

57. Wang, Z. Agricultural Book; Chung Hwa Book Corporation: Beijing, China, 1991.

58. Tang, S.W. Re-Editing the Politics and the History of the Type of Standby Herbs; People's Medical Publishing House: Beijing, China, 1957.

59. Gao, M. Ancient and Modern Talks on Seawater Desalination. Water Conserv. World 1992, 2, 14-15.

60. Zhao, H.B. Overview of the current situation and development trend of seawater desalination technology. In National Seminar on Unconventional Water Utilization Technology; China Desalination Association: Beijing, China, 2010.

61. Baker, M.N. Quest for Pure Water, 2nd ed.; Am. Water Works Assoc.: New York, NY, USA, 1981; Volume 1.

62. Ziadeh, N.A. Early Arab-Islamic culture. Arab. Perspect. 1984, 4, 28-29.

63. Partington, J.R. History of Chemistry Macmillan; Macmillan: London, UK, 1962; Volumes 2-3.

64. Birkett, J. Desalination Activities in England during the Late 17th Century; IWHA: Alexandria, Egypt, 2003.

65. Lyle, O. Efficient Use of Steam; His Majesty's Stationery Office: London, UK, 1945.

66. Natu, G.L.; Goghari, H.O.; Gomkale, S.D. Solar distillation plant at awania, Gujarat, India. Desalination 1979, $31,435-441$. [CrossRef]

67. BARC. Report on the Nuclear Powered Agro-Industrial Complex; BARC Government of India: New Delhi, India, 1970.

68. Misra, B.M.; Sadhukhan, H.K. Desalination and Water Reuse in India-An Overview; EOLSS Publications: New Delhi, India, 2010.

69. Tiwari, G.N.; Sahota, L. General introduction. In Green Energy and Technology; Springer: Berlin/Heidelberg, Germany, 2017; pp. 1-62.

70. Roy, S.; Ragunath, S. Emerging Membrane Technologies for Water and Energy Sustainability: Future Prospects, Constrains and Challenges. Energies 2018, 11, 2997. [CrossRef]

71. Gao, C.J. Brief discussion of seawater desalination. Chem. Technol. Econ. 2003, 11, 24-26.

72. Ding, L.C. The first seawater desalination project in Zhejiang Zhoushan Shengshan Island. Energy Eng. 1999, 2, 8-9.

73. Ruan, G.L.; Xie, L.X.; Lu, Q.C. Seawater reverse osmosis desalination project in Changhai County. Ocean Technol. 2002, 21, 13-16.

74. Fraser-MacDonald, A. Our Ocean Railways; Chapman and Hall: London, UK, 1893.

75. Simon, P. Tapped Out: The Coming World Crisis in Water and What We Can Do about It; Welcome Rain Publishers: New York, NY, USA, 1998.

76. Birkett, J.D. History, Development and Management of Water Resources_Vol. I. The History of Desalination before Large-Scale Use; EOLSS Publications: New Delhi, India, 2010. 
77. Birkett, J.D. The 1861 de Normandy desalting unit at Key West. Int. Desalination Water Reuse Q. 1997, 7, 53-57.

78. Jacob, R.; Jaehnig, K.G. Nor Any Drop to Drink. Distillations. Sci. Hist. Inst. 2018, 4, 8-13.

79. Robbins, J. As Water Scarcity Increases, Desalination Plants Are on the Rise. Yale Environment 360; Yale School of the Environment: Yale, CT, USA, 2019. Available online: https:/ / e360.yale.edu/features/as-water-scarcity-increases-desalination-plants-are-on-the-rise (accessed on 3 May 2021).

80. Salinas, G. Fouling and scaling in seawater reverse osmosis desalination. Source Mag. IWA 2020, 21, 36-39.

81. Oren, Y. Capacitive deionization (CDI) for desalination and water treatment-Past, present and future (a review). Desalination 2008, 228, 10-29. [CrossRef]

82. Gorjian, S.; Ghobadian, B. Solar desalination: A sustainable solution to water crisis in Iran. Renew. Sustain. Energy Rev. 2015, 48, 571-584. [CrossRef]

83. Schorr, M. (Ed.) Desalination: Trends and Technologies; BoD-Books on Demand; Intech Open Access Publisher: New Delhi, India, 2011.

84. Rich, A.; Mandri, Y.; Bendaoud, N.; Mangin, D.; Abderafi, S.; Bebon, C.; Semlali, N.; Klein, J.-P.; Bounahmidi, T.; Bouhaouss, A.; et al. Freezing desalination of sea water in a static layer crystallizer. Desalination Water Treat. 2010, 13, 120-127. [CrossRef]

85. Zotalis, K.; Dialynas, M.G.; Mamassis, N.; Angelakis, A.N. Desalination Technologies: Hellenic Experience. Water 2014, 6, 1134-1150. [CrossRef]

86. Lin, S.; Yip, N.Y.; Cath, T.Y.; Osuji, C.O.; Elimelech, M. Hybrid pressure retarded osmosis-membrane distillation system for power generation from low-grade heat: Thermodynamic analysis and energy efficiency. Environ. Sci. Technol. 2014, 48, 5306-5313. [CrossRef]

87. Shaffer, D.L.; Werber, J.R.; Jaramillo, H.; Lin, S.; Elimelech, M. Forward osmosis: Where are we now? Desalination 2015, 356, 271-284. [CrossRef]

88. Australian NWC [National Water Commission]. Emerging Trends in Desalination: A Review. Waterlines Report Series No. 9. Turner, Australian Capital Territory; Australian NWC: Sydney, Australia, 2008.

89. Voutchkov, N. Desalination-Past, Present and Future. Intern. Water 2016. Available online: https://iwa-network.org/ desalination-past-present-future/ (accessed on 6 May 2021).

90. Low, M.C. Desert dreams of drinking the sea, consumed by the Cold War: Transnational flows of desalination and energy from the Pacific to the Persian Gulf. Environ. Hist. 2020, 26, 145-174. [CrossRef]

91. Leahy, S.; Katherine, P. Peak Salt: Is the Desalination Dream over for the Gulf States? The Guardian. 29 September 2016. Available online: https:/ / www.theguardian.com/global-development-professionals-network/2016/sep/29/peak-salt-is-thedesalination-dream-over-for-the-gulf-states (accessed on 3 May 2021).

92. Schneider-Mayerson, M.; Oil, P. Apocalyptic Environmentalism and Libertarian Political Culture; University of Chicago Press: Chicago, IL, USA, 2015.

93. Lattemann, S.; Höpner, T. Environmental impact and impact assessment of seawater desalination. Desalination 2008, 220, 1-15. [CrossRef]

94. Bashitialshaaer, R.A.; Persson, K.M.; Aljaradin, M. Estimated Future Salinity in the Arabian Gulf, the Mediterranean Sea and the Red Sea Consequences of Brine Discharge from Desalination. Int. J. Acad. Res. 2011, 3, 133-140.

95. Mediterranean Sea. In Encyclopædia Britannica. from Encyclopedia Britannica Online 2009. Available online: http://www. britannica.com/EBchecked/topic/372694/Mediterranean-Sea (accessed on 11 June 2008).

96. Bear, J.; Cheng, A.H.D.; Sorek, S.; Ouazar, D.; Herrera, I. Seawater Intrusion in Coastal Aquifers: Concepts, Methods and Practices; Springer: Berlin/Heidelberg, Germany, 1999; p. 627. [CrossRef]

97. Todd, D.K.; Mays, L.W. Groundwater Hydrology, 3rd ed.; Wiley: Hoboken, NJ, USA, 2004; p. 656.

98. Felisa, G.; Ciriello, V.; Di Federico, V. Saltwater intrusion in coastal aquifers: A primary case study along the Adriatic Coast investigated within a probabilistic framework. Water 2013, 5, 1830-1847. [CrossRef]

99. Mansour, Y.S.A.; Baba, A.; Gunduz, O.; Şimsek, C.; Elçi, A.; Murathan, A.; Sözbilir, H. Modeling of seawater intrusion in a coastal aquifer of Karaburun Peninsula, western Turkey. Environ. Earth Sci. 2017, 76, 775. [CrossRef]

100. Baba, A.; Simsek, C.; Solak, O.; Gunduz, O.; Elci, A.; Murathan, A.; Sozbilir, H. Investigation of sea water intrusion in coastal aquifiers: A case study from Karaburun Peninsula, Turkey. DSİ Tech. Bull. 2016, 120, 14-24. (In Turkish)

101. Karahanoglu, N.; Doyuran, V. Finite element simulation of seawater intrusion into a quarry-site coastal aquifer, Kocaeli-Darıca, Turkey. Environ. Geol. 2003, 44, 456-466. [CrossRef]

102. Kallioras, A.; Pliakas, F.; Diamantis, I. Conceptual model of a coastal aquifer system in northern Greece and assessment of saline vulnerability due to seawater intrusion conditions. Environ. Geol. 2006, 51, 349-361. [CrossRef]

103. Qahman, K.; Larabi, A. Evaluation and numerical modeling of seawater intrusion in the Gaza aquifer (Palestine). Hydrogeol. J. 2006, 14, 713-728. [CrossRef]

104. Sherif, M.; Kacimov, A.; Javadi, A.; Ebraheem, A.A. Modeling groundwater flow and seawater intrusion in the coastal aquifer of Wadi Ham, UAE. Water Resour. Manag. 2012, 26, 751-774. [CrossRef]

105. Gopinath, S.; Srinivasamoorthy, K.; Saravanan, K.; Suma, C.; Prakash, R.; Senthilnathan, D.; Chandrasekaran, N.; Srinivas, Y.; Sarma, V. Modeling saline water intrusion in Nagapattinam coastal aquifers, Tamilnadu, India. Model Earth Syst. Environ. 2016, 2, 2. [CrossRef] 
106. Lin, J.; Snodsmith, J.B.; Zheng, C.; Wu, J. A modeling study of seawater intrusion in Alabama Gulf Coast, USA. Environ. Geol. 2009, 57, 119-130. [CrossRef]

107. Cobaner, M.; Yurtal, R.; Dogan, A.; Mortz, L.H. Three dimensional simulation of seawater intrusion in coastal aquifers: A case study in the Goksu Deltaic Plain. J. Hydrol. 2012, 464, 262-280. [CrossRef]

108. Sarsak, R.; Almasri, M.N. Seawater intrusion into the coastal aquifer in the Gaza Strip: A computer-modelling study. Lancet 2013, 382, S32. [CrossRef]

109. Allow, K.A. Seawater intrusion in Syrian coastal aquifers, past, present and future, case study. Arab. J. Geosci. 2011, 4, 645-653. [CrossRef]

110. Abd-Elhamid, H.F.; Javadi, A.A. A cost-effective method to control seawater intrusion in coastal aquifers. Water Resour. Manag. 2011, 25, 2755-2780. [CrossRef]

111. Gaaloul, N.; Pliakas, F.; Kallioras, A.; Schuth, C.; Marinos, P. Simulation of seawater intrusion in coastal aquifers: Forty five-years exploitation in an eastern coast aquifer in NE Tunisia. Open Hydrol. J. 2012, 6, 31-44. [CrossRef]

112. Surinaidu, L.; Rao, V.V.G.; Mahesh, J.; Prasad, P.R.; Rao, G.T.; Sarma, V.S. Assessment of possibility of saltwater intrusion in the central Godavari delta region, Southern India. Reg. Environ. Chang. 2015, 15, 907-918. [CrossRef]

113. Paniconi, C.; Khlaifi, I.; Lecca, G.; Giacomelli, A.; Tarhouni, J. A modelling study of seawater intrusion in the Korba coastal plain, Tunisia. Phys. Chem. Earth Part B 2001, 26, 345-351. [CrossRef]

114. Werner, A.D.; Bakker, M.; Post, V.E.; Vandenbohede, A.; Lu, C.; Ataie-Ashtiani, B.; Simmons, C.T.; Barry, D.A. Seawater intrusion processes, investigation and management: Recent advances and future challenges. Adv. Water Resour. 2013, 51, 3-26. [CrossRef]

115. Darre, N.C.; Toor, G.S. Desalination of water: A review. Curr. Pollut. Rep. 2018, 4, 104-111. [CrossRef]

116. Suryanarayanan, S. Water Security: Old Problems, New Solutions. Available online: http://www.strategicforesight.com/innerarticles.php?id=121\#.UksOQoZHJjs (accessed on 3 May 2021).

117. Oppili, I. Two New Desalination Plants Set to Augment Water Supply in Chennai. Times of India, 18 September.

118. Sullivan, D.K. Improving the Efficiency of Desalination Membranes. Labroots. Available online: https://www.labroots.com/ trending/chemistry-and-physics/19552/improving-efficiency-desalination-membranes (accessed on 3 May 2021).

119. Gude, V.G. Desalination and water reuse to address global water Scarcity. Rev. Environ. Sci. Biotechnol. 2017, 16, 591-609. [CrossRef]

120. Gude, V.G. Desalination and sustainability-An appraisal and current perspective. Water Res. 2016, 89, 87-106. [CrossRef] [PubMed]

121. Shannon, M.A.; Bohn, P.W.; Elimelech, M.; Georgiadis, J.G.; Marinas, B.J.; Mayes, A.M. Science and technology for water purification in the coming decades. Nature 2008, 452, 301-310. [CrossRef]

122. Voutchkov, N. Energy use for membrane seawater desalination-current status and trends. Desalination 2018, 431, 2-14. [CrossRef]

123. Kumar, M.; Culp, T.; Ahen, Y. Water Desalination: History Advances, and Challenges. In Institutes of Energy and the Environment (IEE); UNIV. of Pennsylvania: Philadelphia, PA, USA, 2016.

124. UNESCO. World Water Day 2020: Desalination Technologies Provide Safe and Sustainable Drinking Water. Available online: https: / / cordis.europa.eu/article/id/415568-world-water-day-2020-desalination-technologies-provide-safe-and-sustainabledrinking-water/es (accessed on 31 July 2020).

125. Alshehri, M.; Bharadwaj, A.; Kumar, M.; Mishra, S.; Gyani, J. Cloud and IoT based Smart Architecture for Desalination Water Treatment. Environ. Res. 2021, 195, 110812. [CrossRef]

126. Leverenz, H.L.; Tchobanoglous, G.; Asano, T. Direct potable reuse: A future imperative. J. Water Reuse Desalination 2011, 1, 2-10. [CrossRef]

127. Chfadi, T.; Gheblawi, M.; Thaha, R. Public acceptance of wastewater reuse: New Evidence from Factor and Regression Analyses. Water 2021, 13, 1391. [CrossRef]

128. Angelakis, A.N.; Vuorinen, H.S.; Nikolaidis, C.; Juuti, P.S.; Katko, T.S.; Rajala, R.P.; Zhang, J.; Samonis, G. Quality of water supply and life expectancy: Parallel courses in time. Water 2021, 13, 752. [CrossRef]

129. Phuong Tram, V.O.; Ngo, H.H.; Guo, W.; Zhou, J.L.; Nguyen, P.D.; Listowski, A.; Wang, X.C. A mini-review on the impacts of climate change on wastewater reclamation and reuse. Sci. Total Environ. 2014, 494-495, 9-17. [CrossRef] [PubMed]

130. Malik, M.A.S.; Tiwari, G.N.; Kumar, A.; Sodha, M.S. Solar Distillation; Pergamon Press: Oxford, UK, 1985.

131. AQUA TECH. Available online: https://www.aquatechtrade.com/news/desalination/worlds-largest-desalination-plants/ (accessed on 12 December 2019). 